\title{
Sargassum Seaweed as a Source of Anti-Inflammatory Substances and the Potential Insight of the Tropical Species: A Review
}

\author{
Saraswati ${ }^{1}$, Puspo Edi Giriwono ${ }^{1,2}$, Diah Iskandriati ${ }^{3}$, Chin Ping Tan ${ }^{4, *}$ and \\ Nuri Andarwulan 1,2,* \\ 1 Department of Food Science and Technology, Faculty of Agricultural Engineering and Technology, \\ Bogor Agricultural University, Bogor 16680, Indonesia; ginasaraswati@gmail.com (S.); \\ pegiriwono@apps.ipb.ac.id (P.E.G.) \\ 2 Southeast Asian Food and Agricultural Science Technology (SEAFAST) Center, Bogor Agricultural \\ University, Bogor 16680, Indonesia \\ 3 Primate Research Center, Bogor Agricultural University, Bogor 16151, Indonesia; atie@indo.net.id \\ 4 Department of Food Technology, Faculty of Food Science and Technology, Universiti Putra Malaysia, \\ Serdang 43400, Malaysia \\ * Correspondence: tancp@upm.edu.my (C.P.T.); andarwulan@apps.ipb.ac.id (N.A.); \\ Tel.: +60-389468418 (C.P.T.); +62-251-862-9903 (N.A.)
}

Received: 23 July 2019; Accepted: 30 August 2019; Published: 17 October 2019

\begin{abstract}
Sargassum is recognized both empirically and scientifically as a potential anti-inflammatory agent. Inflammation is an important response in the body that helps to overcome various challenges to body homeostasis such as microbial infections, tissue stress, and certain injuries. Excessive and uncontrolled inflammatory conditions can affect the pathogenesis of various diseases. This review aims to explore the potential of Sargassum's anti-inflammatory activity, not only in crude extracts but also in sulfated polysaccharides and purified compounds. The tropical region has a promising availability of Sargassum biomass because its climate allows for the optimal growth of seaweed throughout the year. This is important for its commercial utilization as functional ingredients for both food and non-food applications. To the best of our knowledge, studies related to Sargassum's anti-inflammatory activity are still dominated by subtropical species. Studies on tropical Sargassum are mainly focused on the polysaccharides group, though there are some other potentially bioactive compounds such as polyphenols, terpenoids, fucoxanthin, fatty acids and their derivatives, typical polar lipids, and other groups. Information on the modulation mechanism of Sargassum's bioactive compounds on the inflammatory response is also discussed here, but specific mechanisms related to the interaction between bioactive compounds and targets in cells still need to be further studied.
\end{abstract}

Keywords: bioactive compounds; inflammation; mechanism; Sargassum; tropical

\section{Introduction}

Inflammation is known to be a protective strategy that evolves in high-level organisms in response to threats interfering with body homeostasis. Types of threats causing inflammation include microbial infections, tissue stress, and certain injuries [1,2]. The well-known symptoms of classic inflammation are redness, pain, swelling, and fever [3]. Recent literature shows that inflammation operates via an advanced system and has a broad impact on various physiological aspects and human pathology. Although inflammatory response plays a pivotal role in protecting cellular physiological conditions, this process is only needed for a short time to avoid the stages of escalation that result in undesirable conditions, such as collateral tissue damage [1]. Uncontrolled and excessive inflammatory conditions 
can lead to various health problems, for example, multiple sclerosis, cancer, arthritis, atherosclerosis, heart disease, obesity, dermatitis, migraine, irritable bowel disease, insulin resistance, autoimmune, and other diseases [4].

An inflammatory response begins with the recognition of various stimuli by a cellular transmembrane receptor. This condition triggers the transactivation of several important transcription factors, primarily nuclear factor $\mathrm{kB}(\mathrm{NF}-\mathrm{kB})$, which are responsible for the regulation of various genes related to inflammation. In the unstimulated condition, the NF-kB protein is located in the cytoplasm and bound to a protein inhibitor IkB. The degradation of IkB due to upstream inflammatory signals allows NF-kB to undergo nuclear translocation and regulates the downstream inflammatory response by binding to the $\mathrm{kB}$ site in the DNA's structure. This well-known inflammatory signaling is commonly called a canonical pathway. In addition to NF-kB activation, inflammatory stimulation can lead to the activation of MAPK (mitogen-activated protein kinase) pathways, such as ERK (extracellular signal-regulated kinases), p38 MAPK, and JNK (cJun $\mathrm{NH}_{2}$-terminal kinases) [5]. These three protein kinases also play a role in the regulation of genes associated with inflammation through the transactivation of AP-1 proteins. The inflammatory response is generally characterized by the overproduction of prostaglandin $\mathrm{E}_{2}\left(\mathrm{PGE}_{2}\right)$, nitric oxide $(\mathrm{NO})$, pro-inflammatory cytokines (such as tumor necrosis factor (TNF)- $\alpha$, interleukin (IL)-6, and IL-1 $\beta$ ), and increased production of reactive oxygen species (ROS) [6]. The overproduction of $\mathrm{NO}$ and $\mathrm{PGE}_{2}$ are concomitant with the increased activity of inducible nitric oxide synthase (iNOS) and cyclooxygenase-2 (COX-2), respectively. The continuous energy surplus usually occurring in metabolic syndromes can trigger unresolved low-grade chronic inflammation, which may lead to various conditions such as increased oxidative stress, metabolic tissue damage, and/or insulin resistance [7].

Brown seaweed, especially Sargassum, is known to have many health benefits. Fitton [8] concluded that the East Asian lifestyle of using brown seaweed as a part of the staple diet is associated with a low incidence of cancer in the region. Oh et al. [9] reported that the consumption of whole brown seaweeds (including Sargassum fulvellum and S. fusiforme) contributed to ameliorating systemic inflammation and insulin resistance in high fat diet-induced obese mice. Husni et al. [10] also revealed that a diet supplemented by whole seaweed powder (S. hystrix) improved stress-induced liver inflammation conditions in Wistar rats. Based on information in Donguibogam (Korean-Oriental Medical Textbook), seaweeds such as $S$. fulvellum and $S$. thunbergii have been used for generations to treat edema and painful scrotums [11]. Chinese people use various species of Sargassum to treat scrofula, edema, arteriosclerosis, skin diseases, hypertension conditions, liver organ swelling, neurosis, angina pectoris, esophagitis, and chronic bronchitis bronchitis [12]. Studies on utilizing Sargassum as an anti-inflammatory agent are very interesting because this is associated with the empirical application of Sargassum for acute and chronic inflammation. Currently, intensive screening of anti-inflammatory agents from natural ingredients is being undertaken to determine alternatives to established synthetic drugs and is expected to show decreased side effects in humans with inflammatory disorders, particularly chronic inflammation $[4,11,13]$.

This review aims to explore the potential of Sargassum brown seaweeds as a source of anti-inflammatory agents and their modulation mechanisms. Since different latitudes (tropical and subtropical areas) will greatly affect brown seaweed's bioactive components [14,15], special insight on the potential use of tropical Sargassum as an anti-inflammatory agent is discussed here. The tropical region has a promising availability of Sargassum biomass because its climate allows for optimal seaweed growth throughout the year. This climate condition is expected to have an important implication for the commercial exploration of tropical Sargassum as a source of functional ingredients.

\section{Sargassum Species Are a Source of Anti-Inflammatory Agents}

According to the literature summary of Sargassum's anti-inflammatory activity (2005-2019) shown in Tables 1-4, the samples tested were generally divided into three major groups: Crude extracts and their partitions, crude sulfated polysaccharides, and purified compounds from multilevel fractionation. 
Various Sargassum species used in several studies of anti-inflammatory activity originated from two subgenera of Sargassum, namely Bactrophycus and Sargassum.

The Sargassum genus is generally divided into four subgenera: Phyllotrichia, Bactrophycus, Arthrophycus, and Sargassum. This subgenus classification is based on the morphological characteristics of the seaweed thallus. In addition, the distribution pattern can also be used to distinguish between Sargassum subgenera. The most common subgenera found in subtropical/temperate regions are Bactrophycus and Arthrophycus. Subgenus Phyllotrichia is only found in Australia and adjacent areas, while the Sargassum subgenus is widely distributed in tropical areas [16]. Due to the high level of morphological plasticity caused by differences in environmental condition, molecular marker techniques combined with morphological observation are implemented to resolve taxonomic issues [17]. A sequence of the internal transcribed spacer of nuclear ribosomal DNA (ITS) is commonly used to analyze the phylogenetic relationship among Sargassum species. Figure 1 shows the phylogenetic tree of the Sargassum genus based on internal transcribed spacer (ITS)-2 gene sequences. The phylogenetic tree was constructed based on several Sargassum species used in various anti-inflammatory activity studies. The accession number of each gene sequences is obtained from the database of the National Center for Biotechnology Information.

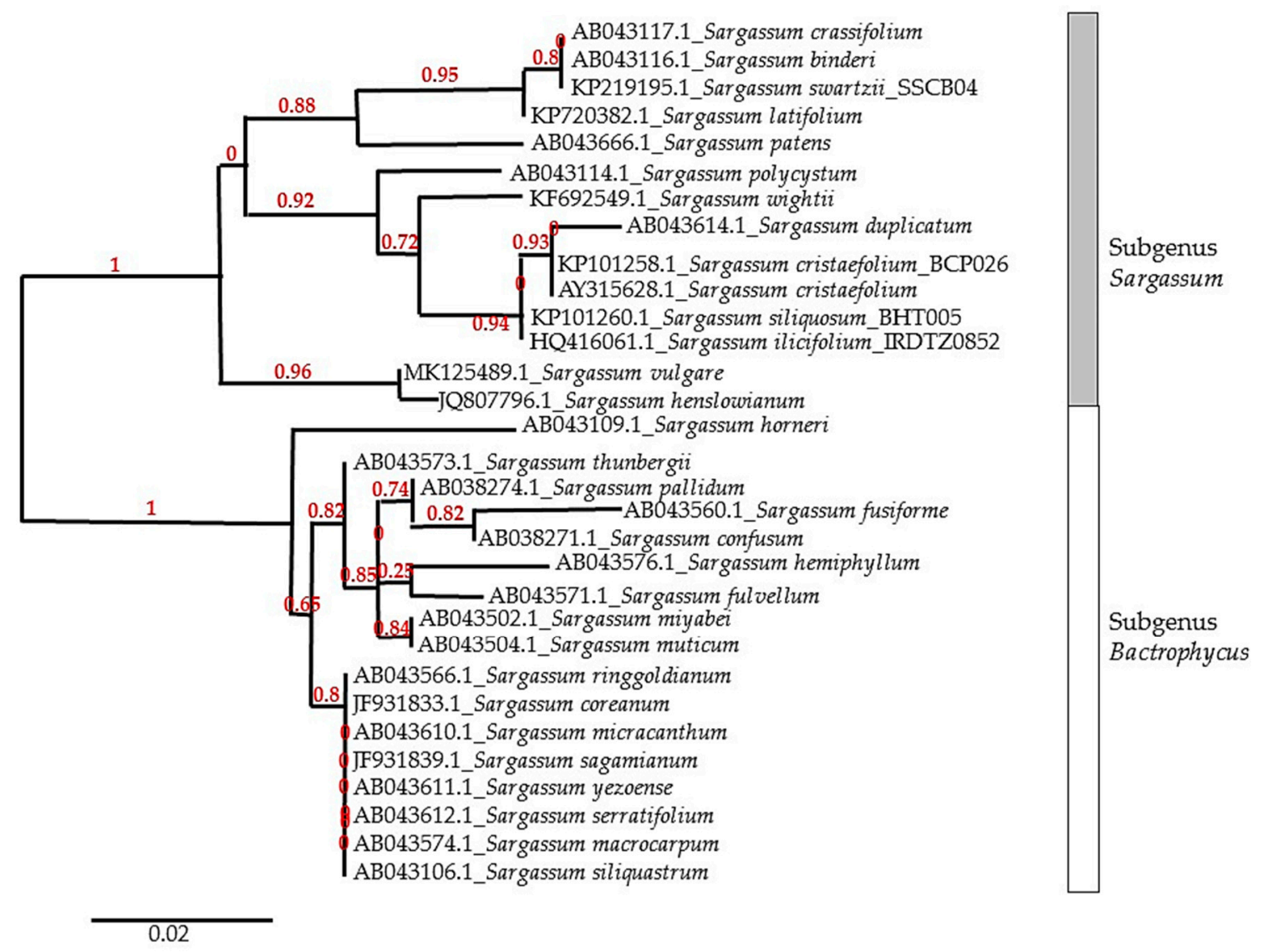

Figure 1. Phylogenetic relationship of genus Sargassum, implemented by the maximum likelihood method based on internal transcribed spacer (ITS-2) gene alignment. The numbers at each node represent the bootstrap value.

\subsection{Crude Extracts and Their Partitions}

An anti-inflammatory activity summary of Sargassum's crude extracts and their partitions is shown in Table 1. Various types of solvents with different polarities are used for extraction and partitioning of the anti-inflammatory compounds. Mun et al. [18] compared the anti-inflammatory activity of the ethanolic extracts from fermented and non-fermented (fresh) samples of the brown seaweed 
S. thunbergii in lipopolysaccharide (LPS)-stimulated RAW 264.7 macrophage cells. Fermentation was initiated in fresh S. thunbergii by inoculation of kimchii-isolated Lactobacillus sp. SH-1. The results showed that fermentation increased the anti-inflammatory effect as indicated by a decreased production of NO and a suppression of iNOS and COX-2 expression. Partitioning of the ethanolic extract resulted in stronger anti-inflammatory activity localized in the relatively lipophilic fractions $(85 \%$ methanol and n-hexane fraction obtained from the chloroform phase). The n-butanol fraction obtained from the water phase exhibited stronger anti-inflammatory activity than the water fraction, which was proven by a decrease in NO production, a suppression of protein and mRNA expression of IL-1 $\beta$, IL- 6 , TNF- $\alpha$, iNOS, and COX-2, and inhibition of MAPKs phosphorylation, especially the JNK pathway. These facts indicated that the relatively lipophilic compounds tended to be responsible for the anti-inflammatory activity. This was supported by several other studies showing a similar tendency that a relatively lipophylic extract or fraction has a promising anti-inflammatory effect [19-33].

Table 1. Studies on the anti-inflammatory activity of Sargassum crude extracts and their partitions.

\begin{tabular}{|c|c|c|c|c|c|}
\hline Sample & & Observed Response & Tested Compound & Model & Ref. \\
\hline S. patens & $\begin{array}{l}\text { (4) } \\
\text { (5) }\end{array}$ & $\begin{array}{l}\text { Decreased NO, prostaglandin } \mathrm{E}_{2} \\
\left(\mathrm{PGE}_{2}\right), \mathrm{IL}-6, \mathrm{TNF}-\alpha \text {, inducible nitric } \\
\text { oxide synthase (iNOS) and } \\
\text { cyclooxygenase (COX)- } 2 \\
\text { production } 1,2 \\
\text { Inhibition of p } 65 \text { nuclear factor kappa } \\
\text { B (NF-kB) translocation }{ }^{1} \\
\text { Decreased ear edema volume and } \\
\text { mastocyte infiltration }^{1}\end{array}$ & Ethanol extract ${ }^{1,2}$ & $\begin{array}{l}\text { LPS-induced RAW } 264.7^{1,2} \text {; } \\
\text { and croton oil-induced rat } \\
\text { ear edema }^{1}\end{array}$ & $\begin{array}{l}1 \text { [37] } \\
2 \text { [38] }\end{array}$ \\
\hline S. wightii & $\begin{array}{l}(1) \\
(2) \\
(3) \\
(4)\end{array}$ & $\begin{array}{l}\text { Significant inhibition of } \\
\text { 5-lipoxygenase (LOX), COX-1, and } \\
\text { COX-2 in vitro }{ }^{1} \\
\text { Inhibition of in vitro albumin } \\
\text { denaturation } 2,6 \\
\text { Decreased paw edema volume }{ }^{3,4,5} \\
\text { Inhibition of red blood cells (RBC) } \\
\text { hemolysis and proteinase activity }^{6}\end{array}$ & $\begin{array}{l}\text { Methanol-ethyl acetate } \\
\text { extract }{ }^{1} \text {; chloroform } \\
\text { extract } 1,3 \text {; ethanol extract } \\
2,3 \text {; hexane extract } 3,6 ; \\
\text { methanol extract } 4,5,6 ; \\
\text { butanol extract }^{4} \text {; and } \\
\text { ethyl-acetate extract } 6\end{array}$ & $\begin{array}{l}\text { In vitro inhibition of } 5 \text {-LOX, } \\
\text { COX- } 1 \text {, and COX- }{ }^{1} ; \\
\text { albumin denaturation } \\
\text { inhibition }{ }^{2,6} ; \\
\text { carrageenan-induced rat } \\
\text { paw edema }{ }^{3,4,5} \text {; and RBC } \\
\text { membrane stabilization and } \\
\text { proteinase inhibition }^{6}\end{array}$ & $\begin{array}{c}1[39]^{*} \\
2[40] \text { * } \\
3[41] \text { * } \\
{ }^{4}[23] \\
5[42] \text { * } \\
{ }^{6}[43]^{*}\end{array}$ \\
\hline $\begin{array}{c}\text { S. } \\
\text { crassifolium }\end{array}$ & \multicolumn{2}{|c|}{ Decreased rat paw edema volume } & $\begin{array}{l}\beta \text {-glucan extract yielded } \\
\text { from acid and ultrasound } \\
\text { methods }\end{array}$ & $\begin{array}{l}\text { Carrageenan-induced rat } \\
\text { (Rattus novergicus) paw } \\
\text { edema }\end{array}$ & {$[48]^{*}$} \\
\hline S. ilicifolium & \multicolumn{2}{|c|}{ Decreased paw edema volume } & Methanol extract; & $\begin{array}{l}\text { Carrageenan-induced rat } \\
\text { paw edema }\end{array}$ & {$[49] *$} \\
\hline
\end{tabular}


Table 1. Cont.

\begin{tabular}{|c|c|c|c|c|}
\hline Sample & Observed Response & Tested Compound & Model & Ref. \\
\hline \multicolumn{5}{|c|}{ Subgenus Sargassum } \\
\hline S. duplicatum & Decreased NO production ${ }^{1,2}$ & $\begin{array}{l}\text { Water extract }{ }^{1} \text {; and } \\
\text { ethanolic precipitate of } \\
\text { water extract }^{2}\end{array}$ & LPS-induced RAW $264.7^{1,2}$ & $\begin{array}{l}1[35]^{*} \\
2[36]^{*}\end{array}$ \\
\hline $\begin{array}{c}\text { S. } \\
\text { subrepandum }\end{array}$ & $\begin{array}{l}\text { Improved plasma lipid profile (plasma } \\
\text { cholesterol, triglycerides, low density } \\
\text { lipoprotein/LDL, and high density } \\
\text { lipoprotein/HDL), decreased serum } \\
\text { malondialdehyde (MDA), NO, TNF- } \alpha \text {, and } \\
\text { leptin production, and increased serum } \\
\text { adiponectin level }\end{array}$ & $\begin{array}{l}\text { Methanol extract } \\
(100 \mathrm{mg} / \mathrm{kg})\end{array}$ & $\begin{array}{l}\text { Atherogenic diet-induced } \\
\text { female Sprague Dawley rats }\end{array}$ & [50] \\
\hline S. polycystum & $\begin{array}{l}\text { (1) Decreased rat paw edema volume }{ }^{1} \\
\text { (2) } \\
\text { Decreased serum TNF- } \alpha \text { and intact } \\
\text { condition of hepatocytes }{ }^{2}\end{array}$ & $\begin{array}{l}\text { Hexane fraction from } \\
\text { methanol extract }{ }^{1} \text {; ethanol } \\
\text { extract } 2,3 \text {; water extract }{ }^{3} \text {; } \\
\text { hexane, dichloromethane, } \\
\text { and methanol extract }{ }^{4}\end{array}$ & $\begin{array}{l}\text { Carrageenan-induced rat } \\
\text { paw edema }{ }^{1} ; \\
\text { acetaminophen-induced } \\
\text { hepatoxicity in rat }{ }^{2} \text {; high } \\
\text { calorie diet and low dose } \\
\text { streptozotocin-induced type } \\
\text { II diabetes }{ }^{3} \text {; and } \\
\text { LPS-induced C8B4 microglia } \\
\text { cells }{ }^{4}\end{array}$ & $\begin{array}{l}1[51]^{*} \\
2[52]^{*} \\
3[53]^{*} \\
4[54]^{*}\end{array}$ \\
\hline S. vulgare & $\begin{array}{l}\text { (1) Decreased rat paw edema volume }{ }^{1} \\
\text { (2) Inhibition of COX-1 and COX-2 } \\
\text { activity }^{2}\end{array}$ & $\begin{array}{l}\text { Methanol extract }{ }^{1} \text {; ethyl } \\
\text { acetate extract }{ }^{2}\end{array}$ & $\begin{array}{l}\text { Carrageenan-induced rat } \\
\text { paw edema }{ }^{1} ; \text { and in vitro } \\
\text { inhibition to COX-1 and } \\
\text { COX-2 enzymes }{ }^{2}\end{array}$ & $\begin{array}{l}{ }^{1}[55] \\
{ }^{2}[56]\end{array}$ \\
\hline \multicolumn{5}{|c|}{ Subgenus Bactrophycus } \\
\hline S. thunbergii & 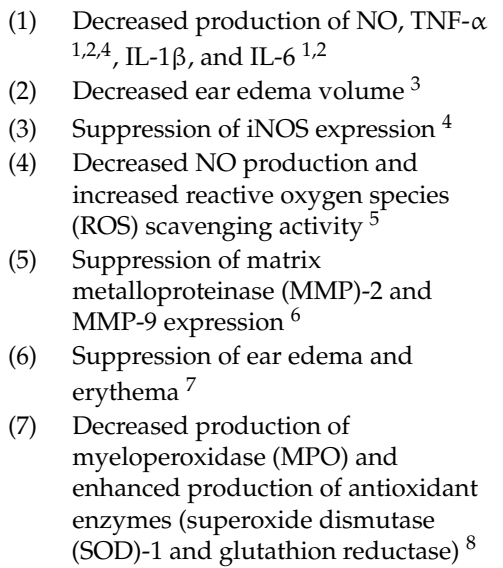 & $\begin{array}{l}\text { Ethanolic extract of } \\
\text { fermented samples and its } \\
\text { fractions }^{1} \text {; ethyl acetate } \\
\text { extract }{ }^{2} \text {; extract of } \\
\text { dichloromethane, ethanol, } \\
\text { and water }{ }^{3} \text {; ethanol } 70 \% \\
\text { extract }{ }^{4} \text {; ethanol extract } \\
\text { and methanol extract } \\
6,7,8\end{array}$ & $\begin{array}{l}\text { LPS-induced RAW } 264.7^{1,2,5} \text {; } \\
\text { rat ear edema }{ }^{3} ; \\
\text { LPS-induced BV-2 microglial } \text { cells }^{4} ; \mathrm{H}_{2} \mathrm{O}_{2} \text {-induced RAW } \\
264.7^{5} ; \text { phorbol } 12 \text {-myristate } \\
13 \text { acetate (PMA)-induced } \\
\mathrm{HT}^{2} 1080^{6} ; \text { PMA-induced } \\
\text { mouse ear edema and } \\
\text { erythema }{ }^{7} ; \text { and TNF- } \alpha \\
\text { stimulated human } \\
\text { monocytic leukemia }\end{array}$ & $\begin{array}{l}1 \\
\begin{array}{l}1 \\
2\end{array}[18] \\
3[2]] \\
4[22] \\
4[58] \\
5[59] \\
6[60] \\
7[61] \\
8[62]\end{array}$ \\
\hline
\end{tabular}

(1) Decreased production of COX-2, iNOS, pro-inflammatory cytokines, $\mathrm{NO}$, and $\mathrm{PGE}_{2} 1,2,3$

(2) Increased expression of $\mathrm{CU} / \mathrm{Zn}$ superoxide dismutase (SOD) and reduced ROS production ${ }^{1}$

(3) Decreased ear edema volume ${ }^{4}$

S. fulvellum (4) Suppressed NO production ${ }^{5,6}$ and reduced cytoplasmic activity ${ }^{5}$,

(5) Decreased serum IL-4, immunoglobulin E (IgE), and TNF- $\alpha$ production, and reduction of IL-4 IL-5, and IL-13 in mice splenocytes 7

Ethyl acetate fraction from ethanol extract ${ }^{1}$, hexane fraction ${ }^{2}$; ethanol extract $^{3,4,7}$;

dichloromethane extract ${ }^{4}$; and water extract 4,5 ; ethanol precipitate of water extract ${ }^{6}$; and methanol extract ${ }^{8}$
Ultraviolet B (UVB)-induced

$\mathrm{HaCaT}$ keratinocytes and

BALB/c mice ${ }^{1 .}$ LPS-induced $\quad{ }^{1}$ [24]

$\begin{array}{ll}\text { BALB/c mice } & \text {; LPS-induced } \\ \text { RAW 264.7 } 2,3,5,6 & \text {; rat ear }\end{array}$

edema ${ }^{3,4}$;

dinitrochlorobenzene

(DNCB)-induced atopic

dermatitis (AD)-like skin

lesions in BALB/c mice ${ }^{7}$;

and PMA-induced mouse ear edema and erythema ${ }^{8}$
3 [64]

4 [22]

$5[35]$ *

$6[36]$ *

7 [65]

8 [61]

(6) Suppression of ear edema and erythema formation 8 
Table 1. Cont.

\begin{tabular}{|c|c|c|c|c|c|}
\hline Sample & & Observed Response & Tested Compound & Model & Ref. \\
\hline \multicolumn{6}{|c|}{ Subgenus Bactrophycus } \\
\hline $\begin{array}{c}\text { S. } \\
\text { serratifolium }\end{array}$ & (5) & $\begin{array}{l}\text { Decreased NO, } \mathrm{PGE}_{2} \text {, iNOS, and COX-2 } \\
\text { production }{ }^{1,2,4} \\
\text { Inhibition of inhibitor kappa B (IkB) } \\
\text { degradation } 1,3 \\
\text { Decreased expression of intercellular } \\
\text { adhesion molecule (ICAM)-1, vascular } \\
\text { cell adhesion molecule (VCAM)-1, } \\
\text { monocyte chemoattractant protein } \\
\text { (MCP)-1, keratinocyte chemoattractant } \\
\text { (KC) }{ }^{3,6} \text {, and MMP-9 } 6 \text {, and elevated } \\
\text { heme oxygenase } 1 \text { expression }{ }^{3} \\
\text { Inhibition of NF-kB transactivation }{ }^{3,4,6} \text {, } \\
\text { MAPKs phosphorylation, and } \\
\text { phosphoinositide } 3 \text { kinase/protein kinase } \\
\text { B (PI3K/Akt) activation }{ }^{4} \\
\text { Decreased expression of MMP-1, MMP-3, } \\
\text { and MMP-13 }{ }^{4} \\
\text { Decreased macrophage infiltration and } \\
\text { MCP-1 expression in epididymal tissue }\end{array}$ & $\begin{array}{l}\text { Ethanol extract } 1,2,4 ; \\
\text { hexane fraction from } \\
\text { ethanolic extract }{ }^{3} \text {; } \\
\text { meroterpenoid-rich extract } \\
\text { from hexane fraction } 5,6\end{array}$ & $\begin{array}{l}\text { LPS-induced mouse } \\
\text { peritoneal macrophage }{ }^{1} ; \\
\text { LPS-induced BV-2 microglial } \text { cells and LPS-induced rat } \\
\text { hippocampus cells }{ }^{2} \text {; } \\
\text { TNF- } \alpha \text {-induced human } \\
\text { umbilical vein endothelial } \\
\text { cells (HUVECs) }{ }^{3,6} ; \\
\text { IL-1 } \beta \text {-treated SW1353 } \\
\text { human chondrocytes }{ }^{4} \text {; high } \\
\text { fat (HF)-fed C57BL/6J mice }{ }^{5} \text {; } \\
\text { and high cholesterol diet } \\
\text { (HCD)-fed C57BL/6 mice }{ }^{6}\end{array}$ & 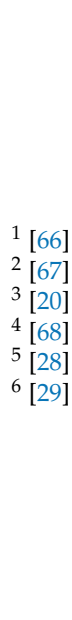 \\
\hline S. miyabei & $\begin{array}{l}\text { (1) } \\
\text { (2) } \\
\text { (3) }\end{array}$ & $\begin{array}{l}\text { Suppressed NO, IL- } 6 \text {, TNF- } \alpha \text {, IL- } 1 \beta \text {, } \\
\text { iNOS, and COX-2 production } \\
\text { Decreased mitogen-activated protein } \\
\text { kinases (MAPKs) and NF-kB activation } \\
\text { Decreased ear edema volume }\end{array}$ & Ethanol extract & $\begin{array}{l}\text { LPS-induced RAW } 264.7 \text { and } \\
\text { rat ear edema }\end{array}$ & [69] \\
\hline S. fusiforme & $\begin{array}{l}(3) \\
(4)\end{array}$ & $\begin{array}{l}\text { Suppressed ear edema formation and } \\
\text { RBL (rat basophilic leukemia) } \\
\text { degranulation }{ }^{1} \\
\text { Decreased activity of phospholipase A2 } \\
\text { (PLA2), COX-2, LOX, and hyaluronidase } \\
1 \\
\text { Decreased NO }{ }^{2,4} \text { and ROS }{ }^{4} \text { production } \\
\text { Decreased TNF- } \alpha \text { production, and } \\
\text { elevated production of IL- } 6 \text { and IL-10 } \\
\text { production }{ }^{3} \\
\text { Decreased NO, iNOS, COX-2, and } \\
\text { pro-inflammatory cytokines production } \\
\text { via inhibition of MAPKs activation }{ }^{5} \\
\text { Suppression of ear edema and erythema } \\
\text { formation }{ }^{6}\end{array}$ & $\begin{array}{l}\text { Administration of diethyl } \\
\text { ether fraction } \\
\text { percutaneously and orally } \\
1 \text {; ethyl acetate fraction } \\
\text { from ethanol } 30 \% \text { extract }{ }^{2} \text {; } \\
\text { water extract }^{3} \text {; methanol } \\
\text { extract and its fractions } \\
\text { (dichloromethane, ethyl } \\
\text { acetate, n-butanol, water) } \\
4 \text {; ethanol extract of } \\
\text { fermented and } \\
\text { non-fermented sample } \\
\text { and methanol extract }\end{array}$ & $\begin{array}{l}\text { Rat ear edema and RBL cells } \\
1, \text { LPS-induced RAW } 264.7 \\
2,4,5 \text {; tert-butyl } \\
\text { hydroperoxide } \\
\text { (t-BHP)-induced RAW } 264.7 \\
\text { RAW } 264.7^{4} \text {; LPS-induced } \\
\text { C2C12 myotube cells }{ }^{3} \text {; and } \\
\text { PMA-induced mouse ear } \\
\text { edema and erythema }^{6}\end{array}$ & $\begin{array}{l}1[31] \\
2[70] \\
3[71] \\
4[33] \\
5[72] \\
6[61]\end{array}$ \\
\hline S. horneri & $\begin{array}{l}\text { (7) } \\
\text { (8) }\end{array}$ & 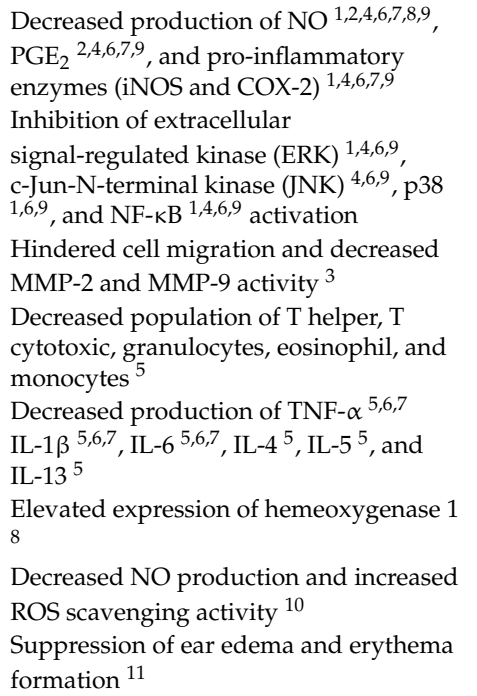 & $\begin{array}{l}\text { Ethanol } 70 \% \text { extract }{ }^{1,4,5} ; \\
\text { ethanol } 85 \% \text { extract }{ }^{2} ; \\
\text { ethanol extract } 3,6,7,10 \text { and } \\
\text { its fraction }{ }^{3,6} ; \text { methanol } \\
80 \% \text { extract and its fraction } \\
8 ; \text { combination of Ecklonia } \\
\text { cava and S. horneri ethanol } \\
70 \% \text { extracts }{ }^{9} ; \text { and } \\
\text { methanol extract } 11\end{array}$ & $\begin{array}{l}\text { LPS-induced RAW } 264.7 \\
1,2,4,6,8,9,10 ; \text { PMA-induced } \\
\text { HT1080 fibrosarcoma }{ }^{3} ; \\
\text { concanavalin A-induced rat } \text { splenocytes }{ }^{5} \text {; fine dust } \\
\text { (FD)-induced RAW } 264.7^{7} ; \\
\text { and PMA-induced mouse } \\
\text { ear edema and erythema }\end{array}$ & $\begin{array}{c}1 \\
{ }^{1}[73] \\
2 \\
{[74]} \\
3 \\
{[30]} \\
4 \\
{[75]} \\
5[76] \\
6[19] \\
7[77] \\
8[78] \\
9 \\
{ }^{9}[79] \\
10[59] \\
{ }^{11}[61]\end{array}$ \\
\hline
\end{tabular}


Table 1. Cont.

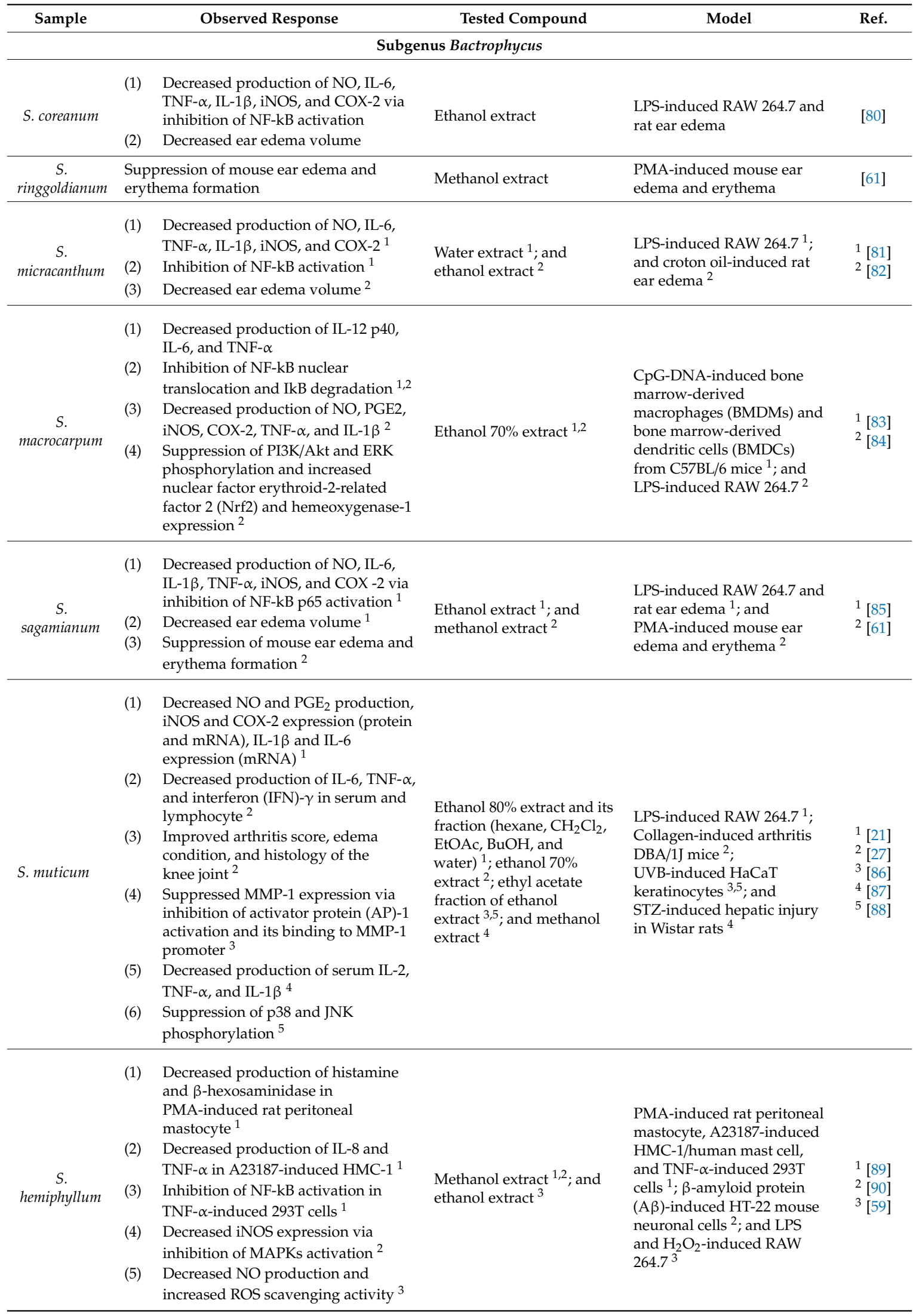


Table 1. Cont.

\begin{tabular}{|c|c|c|c|c|c|}
\hline Sample & & Observed Response & Tested Compound & Model & Ref. \\
\hline \multicolumn{6}{|c|}{ Subgenus Bactrophycus } \\
\hline S. confusum & $\begin{array}{l}(1) \\
(2)\end{array}$ & $\begin{array}{l}\text { Decreased iNOS expression via } \\
\text { inhibition of MAPKs activation }{ }^{1} \\
\text { Suppression of mouse ear edema and } \\
\text { erythema formation }{ }^{2}\end{array}$ & Methanol extract ${ }^{1,2}$ & $\begin{array}{l}\beta \text {-amyloid protein } \\
\text { (A } \beta \text { )-induced HT- } 22 \text { mouse } \\
\text { neuronal cells }{ }^{1} \text {; and } \\
\text { PMA-induced mouse ear } \\
\text { edema and erythema }^{2}\end{array}$ & $\begin{array}{l}1 \text { [90] } \\
2[61]\end{array}$ \\
\hline S. pallidum & $\begin{array}{l}(1) \\
(2)\end{array}$ & $\begin{array}{l}\text { Enhanced production of serum IL-2, } \\
\text { IL- } 4 \text {, and IL-10 } \\
\text { Decreased production of serum IL-6, } \\
\text { IL- } 1 \beta \text {, and TNF- } \alpha\end{array}$ & Water extract & $\begin{array}{l}\text { N-methyl-N'-nitro-nitrosogua } \\
\text { (MNNG)-induced gastric } \\
\text { cancer rats }\end{array}$ & $\begin{array}{l}\text { dine } \\
\text { [92] }\end{array}$ \\
\hline
\end{tabular}

Note: References followed by an asterisk $\left({ }^{*}\right)$ used samples from a tropical area. The superscripted numbering of reference, model, tested compund, and observed response in the same row are related to one another. This superscripted numbering is discontinous between rows and only applied to the same row.

Kang et al. [22] reported that the dichloromethane fraction of S. fulvellum and ethanol fraction of S. thunbergii had a stronger effect in inhibiting mouse ear edema than the water fraction. Based on the GC-MS analysis result of both mentioned fractions, compounds associated with fatty acids and simple organic compounds, such as hexadecanoic acid, neophytadiene, tetradecanoic, 8-heptadecene, and 3,7,11,15-tetramethyl-2-hexadecen-1-ol, dominated the two fractions content. These compounds were thought to be the responsible anti-inflammatory agent. Molecular docking study conducted by Balachandran et al. [93] found that hexadecanoic acid and (E)-9-octadecenoic ethyl ester contained in S. wightii were effective in inhibiting the COX-2 enzyme activity. Several other compounds that are allegedly responsible for the anti-inflammatory activity of the non-polar fraction include fucoxanthin or its derivatives [33], fucosterol or other steroid compounds [20,23,28,29,31,33,51], and phenolic compounds $[18,23,30,31,33]$. Although phenolic compounds are commonly known to have hydrophilic natures, their polarities will actually depend on their chemical structures. A phenolic component consists of various groups with a wide range of structural variations [94]. Various types of lipophilic phenolic components can be found in nature in the form of steryl phenolic acid esters, phenolic acid lactones, phenolic fatty acid esters, and others [95].

In addition to the promising potential of lipophilic extracts/fractions, several studies had shown that a water-soluble extract of Sargassum was also effective in suppressing the inflammatory response [35,44,48,71,81]. Kang et al. [71] reported that the $S$. fusiforme's water extract could suppress the production of TNF- $\alpha$ in the LPS-induced $\mathrm{C} 2 \mathrm{C} 12$ myotube cells and increase the production of cytokines associated with increased insulin sensitivity, such as IL-6 and IL-10. The chemical profile of that water extract was not identified, but the phenolic component was thought to be partially responsible for its anti-inflammatory activity. Jaswir et al. [35] showed that water extracts from several species of Sargassum had an NO inhibitory effect in LPS-induced RAW 267.4 cells, even though the anti-inflammatory activity was not as strong as that of other water extracts obtained from Padina australis and Turbinaria turbinata. They found that the anti-inflammatory activity of the observed brown seaweed water extract was positively correlated with fucose and uronic acid content. Another study showed that the polar $\beta$-glucan extract obtained from $S$. crassifolium has a potent anti-inflammatory activity in the rat ear edema model [48].

Sargassum's crude extract not only shows its effectiveness in the acute inflammatory model but also in the chronic inflammatory model, as reported by several studies $[28,29,44,50]$. The study of Dhas et al. [44] reported that the administration of gold nanoparticles made from a S. swartzii water extract (28 days treatment) improved insulin sensitivity and reduced the serum production of TNF- $\alpha$, IL- 6, and CRP in alloxan-induced diabetic rats. The administration of the methanol extract 
of $S$. subrepandum (four months, $100 \mathrm{mg} / \mathrm{kg}$ body weight) in rats with dyslipidemia triggered an improvement in their plasma lipid profile and reduced the content of MDA, NO, leptin, and TNF- $\alpha$ in rat serum [50]. Dyslipidemia in the mentioned study was triggered by the atherogenic diet given to Sprague Dawley rats for eight consecutive months. Kwon et al. [28] and Gwon et al. [29] proved that the meroterpenoid-rich fraction obtained from ethanolic extract of $S$. serratifolium improved the inflammation condition in both high-fat diet-induced and high-cholesterol diet-induced C57BL/6J mice.

Table 2. Studies on the anti-inflammatory activity of Sargassum crude sulfated polysaccharides (CSP) and their fractions.

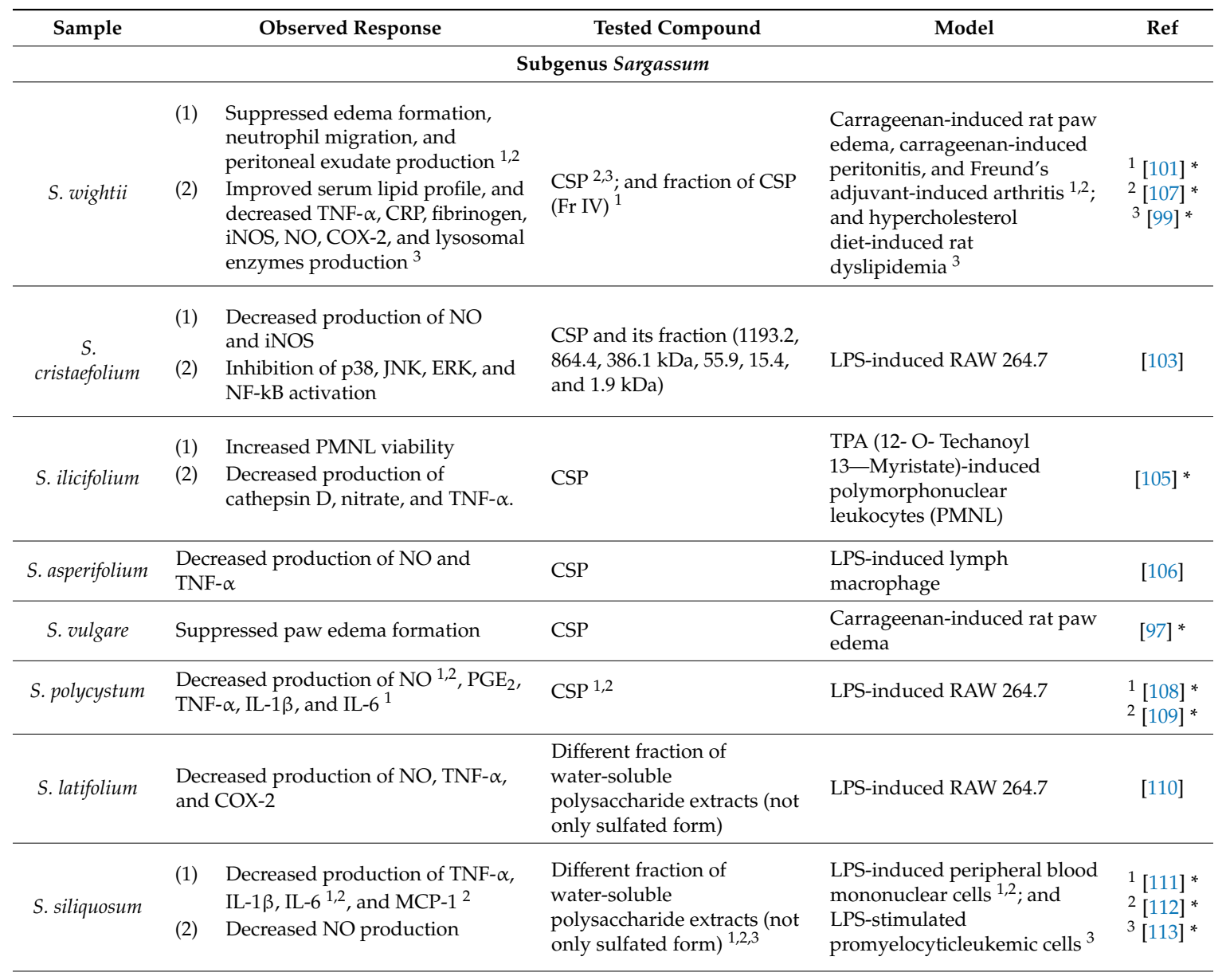

Subgenus Bactrophycus

(1) Decreased production of NO, $\mathrm{PGE}_{2}$, and pro-inflammatory cytokines $1,2,3$

(2) Inhibition of NF-kB activation 1,2 and phosphorylation of $\mathrm{p}-38$ and ERK1/2 2

(3) Decreased NO production in LPS-induced zebra fish ${ }^{1}$
Fraction of CSP yielded from membrane filtration $(<5 \mathrm{kDa}$ (f1), 5-10 kDa (f2), 10-30 kDa (f3), and $>30 \mathrm{kDa}$ (f4)) ${ }^{1}$; and LPS-induced RAW $264.7^{1,2,3}{ }^{1}$ [96] CSP resulted from Celluclast and LPS-induced zebra fish ${ }^{1} \quad 2$ [100] enzyme digestion ${ }^{2}$, CSP and 3 [102] its fractions (Q Sepharose Fast Flow column) ${ }^{3}$

(1) Hindered formation of erythema and ear edema, and decreased S. neutrophil infiltration ${ }^{1}$

hemiphyllum (2) Decreased production of MPO, NO, IL- $1 \beta$, IL-6, and TNF- $\alpha$ in rat ear $^{1}$ and RAW $264.7^{2}$ $\begin{array}{llr} & \begin{array}{l}\text { Arachidonic acid-induced rat } \\ \text { CSP }\end{array} & { }^{1}[104] \\ & \text { RAW 264.7 }\end{array}$

Note: References followed by an asterisk $\left(^{*}\right)$ used samples from tropical area. The superscripted numbering of reference, model, tested compund, and observed response in the same row are related to one another. This superscripted numbering is discontinous between rows and only applied to the same row. 


\subsection{Crude Sulfated Polysaccharides}

Studies on the anti-inflammatory activity of the Sargassum crude sulfated polysaccharides (CSP) have been carried out by several research groups [39,96-107] and are shown in Table 2. Sulfated polysaccharides (SP), such as fucoidan, carrageenan, and ulvan, are recognized as the typical functional compounds derived from various types of marine algae. Fucoidan is a dominant sulfated polysaccharide found in brown seaweed.

Sanjeewa et al. [100] reported that CSP yielded from Celluclast enzyme digestion against S. horneri had the same Fourier transform infrared (FT-IR) spectrum as a commercial fucoidan. Wen et al. [102] found that the purified SP derived from S. horneri (fractionated by column Q Sepharose Fast Flow) contained higher fucose and sulfate ester content than its crude form, and this ester exists along with the elevated anti-inflammatory activity.

The molecular weight $(\mathrm{Mw})$ of SP seems to affect its biological activity. A study of Neelakandan and Venkatesan [101] revealed that a $10 \mathrm{kDa}$ fraction derived from the CSP of S. wightii exhibited stronger anti-inflammatory activity than the fraction with $\mathrm{Mw}>10 \mathrm{kDa}$ and was more effective than its crude extract. The anti-inflammatory effect of their study was demonstrated by the inhibition of edema formation in carrageenan-induced rat paw edema, the suppression of leukocyte and neutrophil migration in the peritonitis model, and inhibition of edema formation in the Freund's complete adjuvant-induced arthritis model. The result of their study controverts the findings of Sanjeewa et al. [96], who reported that the SP fraction with $\mathrm{Mw}>30 \mathrm{kDa}$ was the most effective in suppressing NO production (IC50 $=87.12 \mu \mathrm{g} / \mathrm{mL}$ ) by LPS-induced RAW 264.7 cells among other lower Mw fractions ( $<5,5-10$, and 10-30 kDa). Wu et al. [103] found that the SP fraction with an Mw of $386.1 \mathrm{kDa}$ had the highest NO inhibitory activity compared to other fractions (1193.2, 864.4, 106.3, 55.9, 15.4 , and $1.9 \mathrm{kDa})$. Fractions with a high $\mathrm{Mw}(1193.2,864.4$, and $386.1 \mathrm{kDa})$ tended to have higher anti-inflammatory effects than low Mw fractions (55.9, 15.4, and $1.9 \mathrm{kDa}$ ). The effect of SP's molecular weight on anti-inflammatory activity will depend on various factors, i.e., the testing model, sample, extraction method, and SP structural configuration, including its active groups. The effect of sulfation levels on SP's anti-inflammatory activity was also studied by Wu et al. [103], who found that the $386.1 \mathrm{kDa}$ fraction with $9.42 \%$ sulfate content showed the highest NO inhibition among other samples with different sulfate content $(50.83 \%, 31.01 \%$, and $0.84 \%)$. The SP fraction with $50.83 \%$ sulfate content showed the lowest NO inhibitory effect. Although the study of Wen et al. [102] stated that an increase in sulfate esters in the SP coincided with an enhancement of the anti-inflammatory effect, the study of Wu et al. [103] confirmed that the correlation between them is not always linear.

Fernando et al. [4] summarized that fucoidan functionality will depend on the monosaccharide sequences, sulfation levels, and connectivity of sulfate groups. Fucoidan has a similar characteristic to heparan sulfate, which has an antithrombotic effect with a low bleeding effect [114]. Fucoidan has been reported to inhibit the secretion of gelatinase A and stromelysin in IL-1 $\beta$-induced fibroblasts cells, increase the association of MMPs (matrix metalloproteinases) with their inhibitors (TIMPs), and decrease the activity of leukocyte-secreted elastase. Based on these facts, fucoidan can be used to overcome aberrant extracellular matrix degradation, which usually occurs in inflammatory-related disease. The fucose-containing sulfated polysaccharide (FCSP) term is now considered more relevant than fucoidan because the sugar monomer constituent of common bioactive SP in brown seaweed is not only fucose, but also other sugars such as galactose, rhamnose, mannose, xylose, and glucose [115].

\subsection{Purified Bioactive Compounds}

Some purified compounds of Sargassum, which have been tested for anti-inflammatory activity, include: (1) Terpenoid compounds, such as tuberatolide B, loliolide, sargachromenol, sargachromanol D, sargachromanol G, sargaquinoic acid, sargahydroquinoic acid, isoketochabrolic acid/IKCA, isonahocol E3, and fucosterol fucosterol [19,26,116-129]; (2) fucoxanthin and apo-9'-fucoxanthinone [27,117,130-133]; (3) the polysaccharide group, including alginic acid and pure FCSPs [134-141]; (4) phenolic compounds (phlorotannins) [142,143]; and (5) other groups, such as aryl polyketide lactones and grasshopper 
ketones $[65,144,145]$. A summary can be seen in Tables 3 and 4. Carotenoid compounds, such as fucoxanthin and apo-fucoxanthinone, can also be categorized into the terpenoid group because of the presence of tetraterpenoid derivatives with eight isoprene units [146]. In addition to these compounds, there are other anti-inflammatory compounds contained in brown seaweed: (1) Fatty acids and lipid derivatives such as stearidonic acid (SDA), timnodonic acid, eicosapentaenoic acid (EPA), hexadecanoic acid, 9-octadecenoic ethyl ester, and 7-methoxy-9-methylhexadeca-4,8-dienoic acid and (2) other groups, such as $\gamma$-aminobutyric acid, methyl salicylate, benzoic acid, 2-hydroxyethyl ester, diethyl phthalate, pheophorbide A, and pheophytin [4].

Table 3. The anti-inflammatory activity of Sargassum purified compounds and their mechanisms in modulating inflammation (lipid-soluble compounds).

\begin{tabular}{|c|c|c|c|}
\hline Compound & Source & Modulation of Inflammation & Ref \\
\hline \multicolumn{4}{|c|}{ Terpenoid group } \\
\hline Fucosterol & S. binderi & $\begin{array}{l}\text { Suppression of COX-2, PGE2, TNF- } \alpha \text {, and IL-6 production via the } \\
\text { inhibition of NF-kB activation and MAPK group phosphorylation }\end{array}$ & {$[26]^{*}$} \\
\hline \multirow{4}{*}{ Sargachromenol } & S. serratifolium & $\begin{array}{l}\text { Suppression of adhesion molecules (VCAM-1, and ICAM-1) and } \\
\text { chemotactic cytokine (MCP-1) production via inhibition of IKK- } \beta \text { - } \\
\text { Ik } \beta \text { phosphorylation, and NF-kB nuclear translocation in } \\
\text { TNF- } \alpha \text {-induced HUVECs }\end{array}$ & [123] \\
\hline & S. micracanthum & $\begin{array}{l}\text { Suppression of pro-inflammatory cytokines (TNF- } \alpha \text {, IL-1 } \beta \text {, and IL-6), } \\
\text { PGE2, NO, COX-2, and iNOS production via inhibition of } \operatorname{Ik} \beta \\
\text { degradation in LPS-induced RAW } 264.7\end{array}$ & [126] \\
\hline & S. horneri & $\begin{array}{l}\text { Suppression of MMP-1, -2, and -9 via inhibition of AP-1 activation } \\
\text { (c-Jun and c-Fos) in UVA-induced human derman fibroblast }\end{array}$ & [120] \\
\hline & S. macrocarpum & $\begin{array}{l}\text { Inhibition of JNK and ERK phosphorylation and increased ROS } \\
\text { scavenging activity in UVB-induced HaCaT keratinocytes }\end{array}$ & [121] \\
\hline \multirow{2}{*}{ Sargaquinoic acid } & S. serratifolium & $\begin{array}{l}\text { Suppression of adhesion molecules (VCAM- } 1 \text {, and ICAM- } 1 \text { ) and } \\
\text { chemotactic cytokine (MCP-1, and IL-8) production via inhibition of } \\
\text { Ik } \beta \text { degradation in TNF- } \alpha \text {-induced HUVECs }\end{array}$ & [124] \\
\hline & S. siliquastrum & $\begin{array}{l}\text { Suppression of iNOS and NO production via inhibition of } \operatorname{Ik} \beta \\
\text { degradation, NF-kB nuclear translocation, and JNK1/2 } \\
\text { phosphorylation in LPS-induced RAW } 264.7\end{array}$ & [129] \\
\hline $\begin{array}{l}\text { Sargahydroquinoic } \\
\text { acid }\end{array}$ & S. yezoense & $\begin{array}{l}\text { Suppression of MMP-2/-9 expression via inhibition of NF-kB nuclear } \\
\text { translocation, Ik } \beta \text { degradation, and AP-1 activation in TNF- } \alpha \\
\text { stimulated HaCaT cells }\end{array}$ & [119] \\
\hline Sargachromanol D & S. siliquastrum & $\begin{array}{l}\text { Suppression of pro-inflammatory cytokines (TNF- } \alpha, \text { IL-1 } \beta \text {, and IL-6), } \\
\text { PGE2, NO, COX-2, and iNOS production via inhibition of p65 and } \\
\text { Ik } \beta-\alpha \text { phosphorylation in LPS-induced RAW } 264.7\end{array}$ & [127] \\
\hline Sargachromanol E & S. siliquastrum & $\begin{array}{l}\text { Suppression of pro-inflammatory cytokines (TNF- } \alpha \text {, IL-1 } \beta \text {, and IL-6), } \\
\text { PGE2, NO, COX-2, and iNOS production via inhibition of MAPKs } \\
\text { group phosphorylation (JNK, ERK, and p38) LPS-induced RAW } 264.7\end{array}$ & [118] \\
\hline \multirow{2}{*}{ Sargachromanol G } & S. siliquastrum & $\begin{array}{l}\text { Suppression of pro-inflammatory cytokines (TNF- } \alpha \text {, IL-1 } \beta \text {, and IL-6), } \\
\text { PGE2, NO, COX-2, and iNOS production via inhibition of IkB- } \alpha \text {, } \\
\text { NF- } \mathrm{B} \text { (p65 and p50), and MAPK (ERK1/2, JNK, and p38) } \\
\text { phosphorylation in LPS-induced RAW 264.7 }\end{array}$ & [116] \\
\hline & & $\begin{array}{l}\text { Suppression of osteoclastogenic factor (PGE2, COX-2, IL-6, OPG, and } \\
\text { RANKL) via inhibition of IkB- } \alpha \text {, NF- } \mathrm{kB} \text { (p65 and p50), and MAPKs } \\
\text { (ERK1/2, JNK, and p38) phosphorylation in IL-1 } \beta \text {-induced MG-63 } \\
\text { osteoblast cells }\end{array}$ & [147] \\
\hline $\begin{array}{l}\text { Isoketochabrolic acid } \\
\text { (IKCA) }\end{array}$ & S. micracanthum & $\begin{array}{l}\text { Suppression of pro-inflammatory cytokines (TNF- } \alpha \text {, IL-6, and IL-1 } \beta \text { ), } \\
\text { PGE2, NO, COX-2, and iNOS production in LPS-induced RAW } 264.7\end{array}$ & [125] \\
\hline Tuberatolide B & S. macrocarpum & $\begin{array}{l}\text { Suppression of NO, PGE2, IL-6, IL-1 } \beta \text {, iNOS, and COX-2 production } \\
\text { via inhibition of NF- } \mathrm{B} \text { (p65) and MAPK (ERK1/2, JNK, and p38) } \\
\text { phosphorylation, and IkB degradation LPS-induced RAW 264.7 }\end{array}$ & [122] \\
\hline Isonahocol E3 & S. siliquastrum & $\begin{array}{l}\text { Suppression of IL-6, IL-8, and TNF- } \alpha \text { production, and MMP gene } \\
\text { expression via inhibition of ERK phosphorylation in ET-1-induced } \\
\text { human keratinocytes }\end{array}$ & [128] \\
\hline Loliolide & S. horneri & Suppression of NO production in LPS-induced RAW 264.7 & [19] \\
\hline
\end{tabular}


Table 3. Cont.

\begin{tabular}{|c|c|c|c|}
\hline Compound & Source & Modulation of Inflammation & Ref \\
\hline \multicolumn{4}{|c|}{ Carotenoid group } \\
\hline Fucoxanthin & S. siliquastrum & $\begin{array}{l}\text { Suppression of pro-inflammatory cytokines (TNF- } \alpha, \text { IL-1 } \beta \text {, and IL-6), } \\
\text { PGE2, NO, COX-2, and iNOS production in LPS-induced RAW } 264.7\end{array}$ & [117] \\
\hline \multirow{3}{*}{ Apo- $9^{\prime}$-fucoxanthinone } & \multirow{3}{*}{ S. muticum } & $\begin{array}{l}\text { Suppression of NO }{ }^{1,2}, \text { PGE2, proinflammatory cytokines (TNF- } \alpha, \\
\text { IL-6, and IL-1 } \beta \text { ), iNOS, and COX-2 production via inhibition of } \\
\text { NF-kB (p65) and MAPK (ERK1/2, JNK, and p38) phosphorylation, } \\
\text { and IkB degradation in LPS-induced RAW 264.7 }\end{array}$ & $\begin{array}{l}{[130]^{1}} \\
{[27]^{2}}\end{array}$ \\
\hline & & $\begin{array}{l}\text { Suppression of NO and PGE2 production via inhibition of } \mathrm{Ik} \beta \\
\text { degradation in LPS-induced RAW } 264.7\end{array}$ & [133] \\
\hline & & $\begin{array}{l}\text { Suppression of pro-inflammatory cytokines (IL-12 p } 40 \text {, TNF- } \alpha \text {, and } \\
\text { IL-6) and iNOS production via inhibition of ERK phosphorylation } \\
\text { and AP- } 1 \text { translocation in CpG DNA-induced BMDMs (bone } \\
\text { marrow-derived macrophages) and BMDC (bone marrow-derived } \\
\text { dendritic cells) }\end{array}$ & {$[132]$} \\
\hline \multicolumn{4}{|c|}{ Other group } \\
\hline $\begin{array}{l}\text { Aryl polyketide } \\
\text { lactone }\end{array}$ & S. wightii & Direct inhibition of 5-LOX, COX-2, and COX-1 enzymes (in vitro) & {$[144]^{*}$} \\
\hline Grasshopper ketone & S. fulvellum & $\begin{array}{l}\text { Suppression of pro-inflammatory cytokines (TNF- } \alpha, \text { IL- } 1 \beta \text {, and IL-6), } \\
\text { NO, COX-2, and iNOS production via inhibition of p } 65 \text { NF- } \mathrm{B} \text { B } \\
\text { nuclear translocation and MAPK (ERK1/2, JNK, and p38) } \\
\text { phosphorylation in LPS-induced RAW } 264.7 \\
\text { Suppression of IFN- } \gamma \text { and IL-4 production in concanavalin-A-induced } \\
\text { BALB/c mice splenocytes }\end{array}$ & $\begin{array}{c}{[145]} \\
{[65]}\end{array}$ \\
\hline
\end{tabular}

Note: References followed by an asterisk $\left({ }^{*}\right)$ used samples from tropical area. The superscripted numbering as listed in reference and modulation of inflammation in the same row are related to one another. This superscripted numbering is discontinous between rows and only applied to the same row.

Table 4. Anti-inflammatory activity of Sargassum purified compounds and their mechanism in modulating inflammation (water-soluble compounds).

\begin{tabular}{|c|c|c|c|}
\hline Compound & Source & Modulation of Inflammation & Ref \\
\hline \multicolumn{4}{|c|}{ Polysaccharides } \\
\hline \multirow{4}{*}{$\begin{array}{l}\text { Purified FCSPs } \\
\text { (fucoidan) }\end{array}$} & S. wightii & $\begin{array}{l}\text { Direct inhibition of 5-LOX, COX-2, and COX-1 enzymes } \\
\text { (in vitro). }\end{array}$ & {$[136]^{*}$} \\
\hline & S. henslowianum & $\begin{array}{l}\text { Increased secretion of anti-inflammatory cytokines (IL-2, IL-4, } \\
\text { and IL-10) and suppression of pro-inflammatory cytokines } \\
\text { (IL-6 and TNF- } \alpha \text { ) production in MNNG-induced gastric } \\
\text { cancer rats. }\end{array}$ & [134] \\
\hline & S. hemiphyllum & $\begin{array}{l}\text { A combination of oligofucoidan (LMF) and fucoxanthin } \\
\text { resulted in enhancement of the intestinal epithelial barrier and } \\
\text { immune function against LPS stimulation through } \\
\text { suppression of IL-1 } 1 \beta \text { and TNF- } \alpha \text { production and increased } \\
\text { secretion of IL-10 and IFN- } \gamma \text { in CaCo2 cells co-cultured with } \\
\text { B. lactis } 1 \\
\text { A combination of oligofucoidan (LMF) and fucoxanthin } \\
\text { resulted in enhancement of adiponectin production, and } \\
\text { decreased production of TNF- } \alpha \text { and IL- } 6 \text { in type II diabetes } \\
\text { mouse model }{ }^{2}\end{array}$ & $\begin{array}{l}{[137]^{1}} \\
{[141]^{2}}\end{array}$ \\
\hline & S. horneri & $\begin{array}{l}\text { Decreased NO production }(\mathrm{IC} 50=40 \mu \mathrm{g} / \mathrm{mL} \text { ) via inhibition of } \\
\text { the NF- } \mathrm{kB} \text { and MAPK }(\mathrm{ERK} \text { and } \mathrm{p} 38) \text { signaling pathways in } \\
\text { LPS-stimulated RAW } 264.7 \text { cells. } \\
\text { Decreased heart-beating rate, cell death, ROS, and NO levels } \\
\text { in LPS-exposed zebrafish embryos. }\end{array}$ & [140] \\
\hline
\end{tabular}


Table 4. Cont.

\begin{tabular}{|c|c|c|c|}
\hline Compound & Source & Modulation of Inflammation & Ref \\
\hline & & Polysaccharides & \\
\hline \multirow[b]{2}{*}{ Alginic acid } & S. horneri & $\begin{array}{l}\text { Suppression of PGE2, proinflammatory cytokines (TNF- } \alpha \text {, } \\
\text { IL-6, and IL-1 } \beta \text { ), and COX-2 production via inhibition of } \\
\text { NF- } \mathrm{B} \text { (p65) nuclear translocation and MAPK (ERK1/2, JNK, } \\
\text { and p38) phosphorylation in CFD (Chinese fine dust)-induced } \\
\text { HaCaT keratinocytes. }\end{array}$ & {$[135]$} \\
\hline & S. wightii & $\begin{array}{l}\text { Suppression of COX-2, 5-LOX, MPO, xanthine oxidase }(\mathrm{XO}) \text {, } \\
\text { ceruloplasmin, rheumatoid factor, CRP, pro-inflammatory } \\
\text { cytokines, and lysosomal enzymes in type-2 collagen-induced } \\
\text { rat arthritis. } \\
\text { Suppression of COX-2, 5-LOX, MPO, XO, ceruloplasmin, } \\
\text { rheumatoid factor, and CRP production, and enhancement of } \\
\text { antioxidant enzymes activity in Freund's complete } \\
\text { adjuvant-induced rat arthritis. }\end{array}$ & {$[139] *$} \\
\hline & & Phenolic compounds & \\
\hline \multirow[t]{2}{*}{ Phlorotannin } & S. muticum & $\begin{array}{l}\text { Suppression of ROS production in PMA-induced neutrophil } \\
\text { and suppression of PGE2, COX-1, and COX-2 expression in } \\
\text { A23187-induced erythrocytes. }\end{array}$ & {$[142]$} \\
\hline & S. vulgare & $\begin{array}{l}\text { Suppression of NO production in LPS-induced RAW } 264.7 \\
\text { and direct scavenging of NO in a cell-free system. }\end{array}$ & {$[143]$} \\
\hline
\end{tabular}

Note: References followed by an asterisk $\left(^{*}\right)$ used samples from tropical area. The superscripted numbering as listed in reference and modulation of inflammation in the same row are related to one another. This superscripted numbering is discontinous between rows and only applied to the same row.

According to the above summary, there are still many potential anti-inflammatory compounds from the Sargassum species to be unraveled, especially groups of fatty acids and lipid derivatives. Some Sargassum species are reported to be rich in anti-inflammatory fatty acids, primarily EPA (C20:5n3) and SDA (C18:4n3) [14,148]. Chen et al. [148] revealed that some Sargassum species often used in traditional Chinese medicine have satisfactory ratios of polyunsaturated fatty acid (PUFA) to saturated fatty acid (SFA; >0.45) and n-6/n-3 (<10), which can improve pathological conditions in cardiovascular diseases, which are strongly related to inflammatory disorders. Some essential PUFAs in Sargassum, especially EPA and SDA, are incorporated into glycolipid structures [149-151]. PUFA-rich polar lipids in Sargassum, including the glycolipid group, are reported to have biological activities that benefit human health, such as fibrinolytic and anti-cancer activities [149,152]. The NMI fatty acid (non-methylene interrupted, C20:2n11,16) found in S. marginatum is thought to correlate with apoptotic activity in human blood cancer cells (HL-60) [149].

\subsubsection{Terpenoids}

Terpenoids are a large group of secondary metabolites. This compound is composed of isoprene units (2-methyl-1,3 butadiene, $\mathrm{C}_{5} \mathrm{H}_{8}$ ) and produced by the biosynthesis process with mevalonate as a parent [153]. Sterol is a triterpenoid derivative containing six units of isoprene, and fucosterol is a dominant sterol commonly found in brown seaweed [4]. Several mentioned compounds such as tuberatolide B, sargachromenol, sargachromanol D, sargaquinoic acid, sargahydroquinoic acid, and isonahocol E3 are included in the meroterpenoid group. The group of meroterpenoid is characterized to possess a polyprenyl structure bound to hydroquinone or similar aromatic rings [12]. Isoketochabrolic acid (IKCA) belongs to the C18 terpenoid-related carboxylic acids group [154]. Loliolide or 6-hydroxy-4,4,7a-trimethyl-5,6,7,7a-tetrahydrobenzofuran-2(4H)-one (HTT) is included to the monoterpenoid hydroxylactone group [155]. Various terpenoid compounds have been shown to play an important role as modulators in the NF-kB signaling pathway, so this group of compounds is known as a potent anti-inflammatory agent [153]. The non-polar characteristic of terpenoids will make them diffuse into inflamed cells easily, and may produce a rapid effect in modulating the inflammatory response. Chemical structures of several terpenoid compounds can be seen in Figure 2. 
<smiles>C/C=C(\CCC(C)[C@H]1CCC2C3CC=C4CC(O)CCC4(C)C3CCC21C)C(C)C</smiles>

(a)

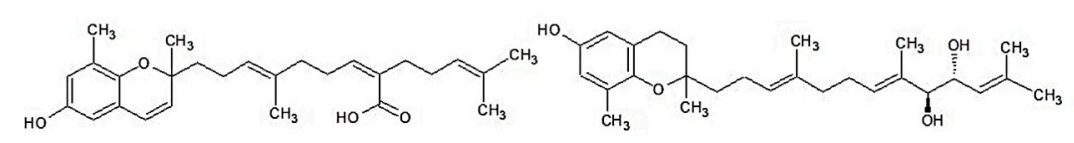

(b)<smiles>CC(C)=CC(O)C(O)/C(C)=C/CC/C(C)=C/CCC1(C)CCc2cc(O)cc(C)c2O1</smiles>

(e)

(c)<smiles>CC(C)=CC(O)C(=O)C(C)=CCCC(C)=CCCC1(C)CCc2cc(O)cc(C)c2O1</smiles>

(f)<smiles>CC(=O)CC/C=C(\C)CC/C=C(/CCC=C(C)C)C(=O)O</smiles>

(g)

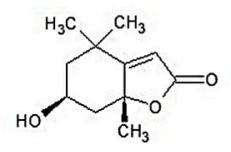

(h)<smiles>CC(=O)Cc1cc(O)cc(C/C=C(\C)CC/C=C(\C)CCCC(C)C(=O)C(O)C=C(C)C)c1O</smiles>

(i)

(j)

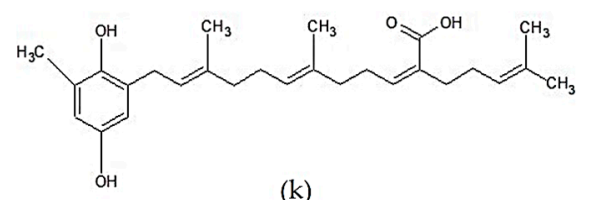

(k)

Figure 2. Chemical structures of several terpenoid compounds of Sargassum sp.: (a) fucosterol [156], (b) sargachromenol [126], (c) sargaquinoic acid [126], (d) sargachromanol D [157], (e) sargachromanol E [158], (f) sargachromanol G [159], (g) isoketochabrolic acid [125], (h) loliolide [160], (i) tuberatolide B [161], (j) isonahocol E3 [128] “Reprinted from European Journal of Pharmachology, 720/1-3, Sah et al., Novel isonahocol E3 exhibits anti-inflammatory and anti-angiogenic effects in endothelin-1-stimulated human keratinocytes, 205-211, Copyright (2013), with permission from Elsevier", and (k) sargahydroquinoic acid [162].

\subsubsection{Fucoxanthin and Its Derivatives}

Fucoxanthin is the dominant carotenoid in brown seaweed, which can absorb the light spectrum in the range of 450-540 nm. Fucoxanthin has a unique structure, which includes allenic bonds, conjugated carbonyl, epoxides, and acetyl groups. Carotenoids are usually found in nature as trans isomers. However, cis-isomers can still be found in small amounts due to the isomerization process. Several studies have shown that the cis-trans configuration of a carotenoid isomer affects its bioactivity $[117,163,164]$. Heo et al. [117] showed that all-trans-(6'R) fucoxanthin isomer more effectively inhibited NO and TNF- $\alpha$ production in LPS-stimulated RAW 264.7 cells than its cis isomers (9'-cis- $\left(6^{\prime} R\right)$ fucoxanthin and a complex of 13-cis $\left(6^{\prime} R\right)$ fucoxanthin and $13^{\prime}$-cis- (6'R) fucoxanthin). A complex of the 13-cis and $13^{\prime}$-cis- $\left(6^{\prime} \mathrm{R}\right)$ fucoxanthin isomer showed significant cytotoxicity in cells, so the anti-inflammatory effect can be associated with its cytotoxicity. Apo-9-fucoxanthinone, a product of fucoxanthin degradation, is also reported to have promising anti-inflammatory activity [27,130-133]. Chemical structures of fucoxanthin and its derivatives are shown in Figure 3. 


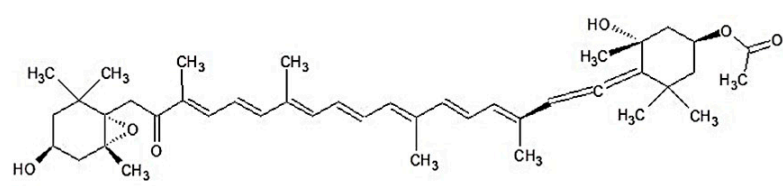

(a)<smiles>CC(=O)OC1C[C@H](C)C(=C=C=CC(C)=CC=CC(C)=CC=CC=C(C)C=CC=C(C)C(=O)CC2(C)C(C)C[C@@H](O)CC2(C)C)C(C)(C)C1</smiles><smiles>C/C=C\C(C)=C/C=C/C=C(C)\C=C\C=C(/C)C(=O)CC1[C@H](C)C[C@@H](O)CC1(C)C</smiles><smiles>CC(=O)C=C1C(C)(C)CC(OC(C)=O)CC1(C)C</smiles>

(e) (c)

(c)

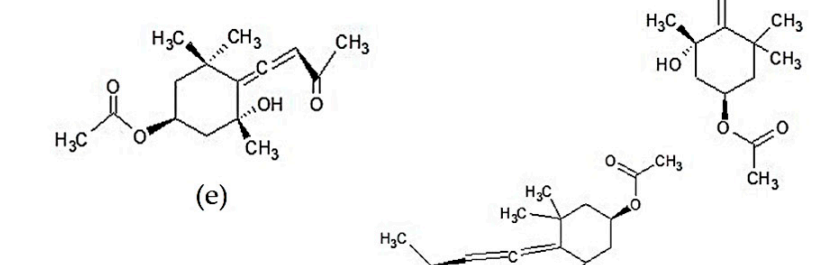

Figure 3. The chemical structures of fucoxanthin and its derivatives of Sargassum sp.: (a) all-trans-(6'R)-fucoxanthin [165], (b) 9-cis-(6'R)-fucoxanthin [117], (c) 13'-cis-(6'R)-fucoxanthin [117], (d) 13-cis-(6'R)-fucoxanthin [117] "Reprinted from Food and Chemical Toxicology, 50/9, Heo et al., Anti-inflammatory effect of fucoxanthin derivatives isolated from Sargassum siliquastrum in lipopolysaccharide-stimulated RAW 264.7 macrophage, 3336-3342, Copyright (2012), with permission from Elsevier", and (e) apo-9'-fucoxanthinone [166].

\subsubsection{Other Lipid-Soluble Compounds}

The other types of lipid-soluble anti-inflammatory compounds that have been reported are polyketide macrolactone and grasshopper ketone. Chemical structures of those compounds can be seen in Figure 4. Polyketide is a secondary metabolite compound characterized by the presence of alternating carbonyl and methylene groups and is generally produced by fungi [167]. Maneesh et al. [144] succeeded in isolating two types of aryl-polyketide lactone compounds from S. wightii. These compounds had strong anti-inflammatory and antioxidant activity. The two isolated compounds are 4-(8-ethyl-tetrahydro-7-oxo-2H-pyran-5-yl)-propyl-4'-methyl benzoate (compound 1) and methyl-2-(12-oxo-7-phenyl-8-vinyl-1-oxa-4,9- cyclododecadien-3-yl)-acetate (compound 2). The study found that the isolated aryl polyketide lactones had a more effective 5-LOX and COX-2 inhibitory activity than standard synthetic drugs, such as ibuprofen and sodium salicylate, and had higher COX-2/COX-1 selectivity than aspirin and ibuprofen. The inhibitory activity of the aforementioned compounds against 5-LOX, COX-2, and COX-1 enzymes is strongly influenced by their electronic and hydrophobic characteristics. Electron-rich centers, such as the cyclic esters and vinyl or aryl substituents contained in aryl polyketide lactones, act as unsaturation centers determining the inhibition effect on pro-inflammatory enzymes.

The grasshopper ketone (GK) or 4-[(2R,4S)-2,4-dihydroxy-2,6,6-trimethylcyclohexylidene]but-3-en2-one was successfully isolated from the hexane fraction of S. fulvellum by Kang et al. [65] and Kim et al. [145]. GK was found to significantly decrease cytokine production in concanavalin A-stimulated splenocytes BALB/c mice with no cytotoxicity [65]. This compound also significantly inhibited the production of iNOS, COX-2, and several pro-inflammatory cytokines in LPS-induced RAW 264.7 [145]. 


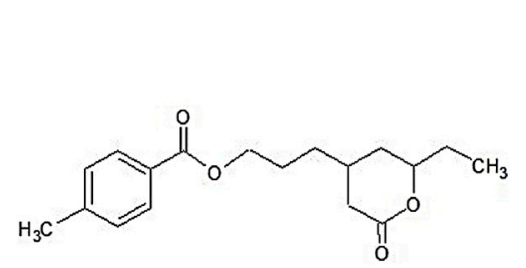

(a)

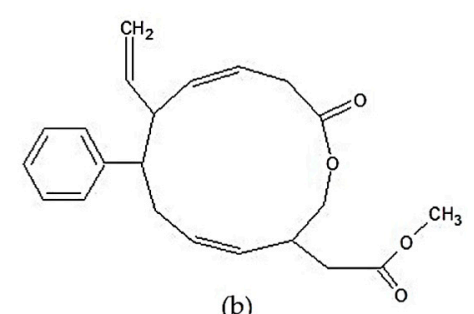

(b)<smiles>CC(=O)C=C=C1C(C)(C)C[C@@H](O)C[C@]1(C)O</smiles>

(c)

Figure 4. Chemical structures of other lipid-soluble compounds of Sargassum sp.: (a) 4-(8-ethyltetrahydro-7-oxo-2H-pyran-5-yl)-propyl-4'-methyl benzoate, (b) methyl-2-(12-oxo-7-phenyl-8-vinyl1-oxa-4,9- cyclododecadien-3-yl)-acetate [144] "Reprinted from Food Research International, 100, Maneesh A. and Chakraborty K., Unprecedented antioxidative and anti-inflammatory aryl polyketides from the brown seaweed Sargassum wightii, 640-649, Copyright (2017), with permission from Elsevier", and (c) grasshopper ketone [168].

\subsubsection{Polysaccharides}

The most abundant active polysaccharides derived from brown seaweed are FCSPs and alginic acid. Their chemical structures can be seen in Figure 5. The main constituent of FCSPs is L-fucopyranose, which may be substituted with sulfate or acetate and/or have side branches containing fucopyranoses or other glycosyl units [169]. Alginic acid is anionic polysaccharide consisting of $\beta$-D-mannuronate and $\alpha$-L-guluronate as basic monomers. Alginic acid is reported to exhibit potential anti-inflammatory activity in the rat arthritis model induced by type-2 collagen and Freund's complete adjuvant $[138,139]$.

The majority of exploratory studies of pure compounds from Sargassum (Table 3) use single components as the only responsible agent in improving inflammatory conditions, except for the studies by Hwang et al. [137] and Lin et al. [141].Hwang et al. [137] found that the combination of LMF (low molecular weight fucoidan; with a Mw around $0.8 \mathrm{kDa}$ ) and HS-Fucox (high stability fucoxanthin) derived from $S$. hemiphyllum effectively suppressed inflammatory response in LPS-induced $\mathrm{CaCo} 2$ cells co-cultured with Bifidobacterium lactis. This was indicated by a decreased production of TNF- $\alpha$ and IL- $1 \beta$, as well as increased production of anti-inflammatory cytokines such as IL-10 and IFN- $\gamma$. In addition, the treatment of LMF-HS Fucox also helped maintain intestinal epithelial cell integrity, which was indicated by an increase in the mRNA expression encoding the tight junction protein (occludin, claudin-1, and claudin-2). LMF can promote the growth of probiotic B. Lactis, thereby helping to maintain the structural integrity of colon cells. Park et al. [170] reported that LMF (Mw $\pm 1 \mathrm{kDa}$ ) has a stronger NO inhibition effect than the high molecular weight fucoidan/HMF (Mw $\pm 100 \mathrm{kDa})$ in the LPS-induced RAW 264.7 cells. In the model of type 2 collagen-induced arthritis, oral administration of HMF (300 mg/kg, 49 days) exacerbated the severity of arthritis and inflammatory conditions in joint cartilage, whereas LMF treatment reduced arthritis severity and the levels of Th1-dependent collagen-specific $\operatorname{IgG}_{2 a}$. This contradicts the findings of Sanjeewa et al. [96] and Wu et al. [103], as discussed in the previous section. These two studies also observed the NO inhibition level in a similar cell culture model. Sanjeewa et al. [96] obtained an FCSP-rich fraction through filtration techniques, while Wu et al. [103] obtained crude FCSPs with different molecular weights using the acid hydrolysis technique (also as conducted by Park et al. [170]). This contradiction could not be further explained because the chemical characteristic information for each FCSP fractions is limited, especially for the sulfation level which may greatly determine the bioactivity of FCSPs $[103,171]$. 


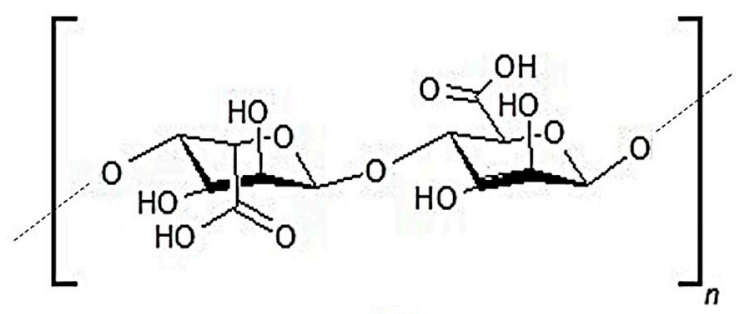

(a)

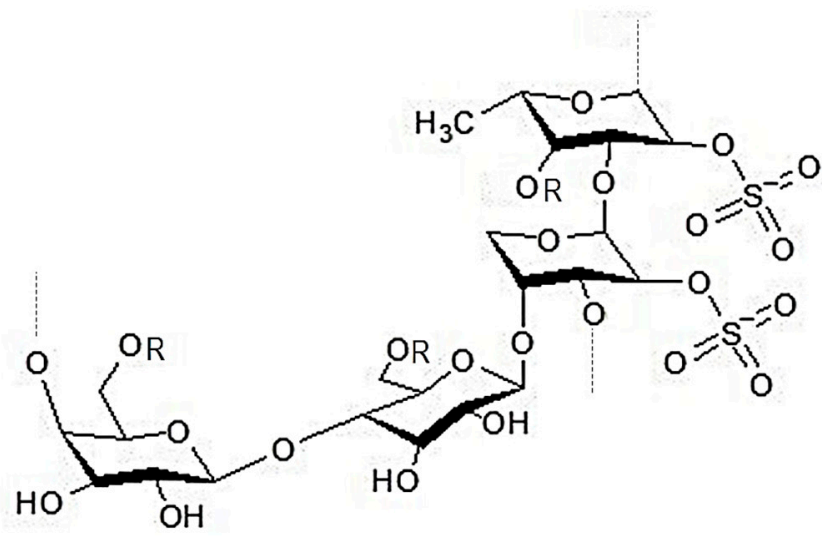

Note: $R=H /$ methyl/acetyl

(b)

Figure 5. Chemical structures of the polysaccharide compounds of Sargassum sp.: (a) Alginic acid [172] and (b) sulfated polygalactopyanosil fucopyranan (an example of purified fucose-containing sulfated polysaccharides (FCSPs)) [136] “Reprinted by permission from [Springer Nature Customer Service Centre GmbH]: [Springer Nature] [Journal of Applied Phycology] [Pharmacological potential of sulfated polygalactopyranosyl-fucopyranan from the brown seaweed Sargassum wightii, Maneesh A. And Chakraborty K), [COPYRIGHT] (2018)".

\subsubsection{Phenolic Compounds}

Phlorotannin is a typical phenolic group of brown seaweed. These compounds have a broad molecular size range (from $126 \mathrm{Da}$ to $650 \mathrm{kDa}$ ) and are divided into six main classes, fucols, phloretols, fucophlorethols, fuhalols, isofuhalols, and eckols. Phlorotannin is composed of phloroglucinol units (1,3,5-trihydroxybenzene) with different degrees of polymerization. The classification of phlorotannin is based on the different bond types between their constituent units [143]. Lopes et al. [143] reported that the phlorotannin content in some types of seaweed belonging to the Sargassaceae family ranged from 74.96 to $815.82 \mathrm{mg}$ phloroglucinol $/ \mathrm{kg}$. The main phlorotannin classes found in Sargassum are fuhalols, phlorethols, and fucophlorethols [173-175]. Li et al. [173] reported that the phlorotannin in S. fusiforme was dominated by a fuhalol group with DP of 2-12. Lopes et al. [143] proved that phlorotannin affected the NO levels in LPS-induced RAW 264.7 through NO direct scavenging and/or the modulation of inflammatory signals in cells. The anti-inflammatory activity of phlorotannin is strongly influenced by its qualitative composition. The chemical structures of phloroglucinol and examples of several phlorotannin classes commonly found in Sargassum are shown in Figure 6. 
<smiles>Oc1cc(O)cc(O)c1</smiles>

(a)

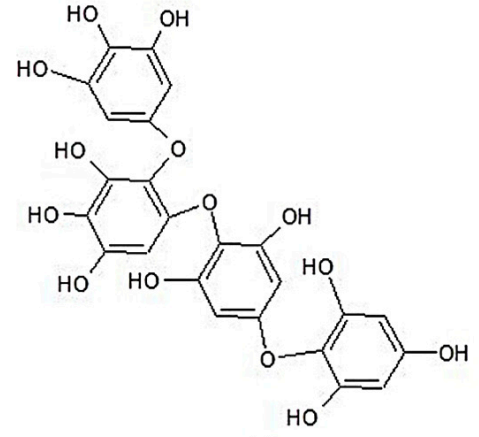

(c)<smiles>Oc1cc(O)c(Oc2cc(O)cc(O)c2Oc2c(O)cc(O)cc2O)c(O)c1</smiles>

(b)<smiles>Oc1cc(O)c(-c2c(O)cc(Oc3c(O)cc(Oc4cc(O)cc(O)c4O)cc3O)cc2O)c(O)c1</smiles>

(d)

Figure 6. Chemical structures of the phenolic compounds of Sargassum sp.: (a) Phloroglucinol (a monomer of phlorotannin), (b) tetraphloretol B (an example of the phlorethol group), (c) tetrafuhalol A (an example of the fuhalol group), and (d) fucodiphlorethol A (an example of the fucophlorethol group) [143].

\section{The Potency of Tropical Sargassum as an Anti-Inflammatory Agent}

\subsection{Latest Reports on Anti-Inflammatory Activity of Tropical Sargassum}

The majority of Sargassum crude extracts tested on anti-inflammatory screening are derived from subtropical samples. Seventeen out of 73 studies used samples from tropical regions [34-36,39-45,47-49,51-54]. Most of the observed tropical species came from subgenus Sargassum, including S. polycystum, S. wightii, S. swartzii, S. crassifolium, S. binderi, and S. ilicifolium. Some subtropical species tested in the crude extract studies were dominated by the subgenus Bactrophycus, including S. hemiphyllum, S. muticum, S. sagamianum, S. macrocarpum, S. micracanthum, S. coreanum, S. horneri, S. fusiforme, S. miyabei, S. serratifolium, S. fulvellum, S. confusum, S. siliquastrum, S. pallidum, $S$. ringgoldianum, and $S$. thunbergii. However, some species belonging to the subgenus Sargassum can also be found in subtropical areas, such as S. patens, S. wightii, S. vulgare, S. subrepandum, and S. swartzii $[23,37,38,46,50,55,56]$. The differentiation between tropical and subtropical samples is based on the thorough evaluation of the sampling location or coordinates information provided in each study. Tropical samples originated from area near the equator (from $23.5^{\circ}$ further north to $23.5^{\circ}$ southern latitude). While subtropical samples originated from area between $23.5^{\circ}$ and $66.5^{\circ}$ north and south. Some models used in the screening studies of tropical Sargassum's crude extracts are rat edema $[41,42,45,48,49,51]$, the in vitro inhibition of 5-LOX, COX-2, and COX-1 enzymes [39], the stabilization of red blood cell (RBC) membrane [43], in vitro inhibition of albumin denaturation [40,43], and inhibition of proteinases [43]. These models are still unable to fully describe the comprehensive mechanisms of bioactive compounds in inhibiting the inflammatory process. Some studies tried to screen the anti-inflammatory activity of several tropical Sargassum varieties using the RAW 264.7 cell model, but the available mechanism information is only limited to the inhibition of NO production after LPS stimulation [35,36,47,54]. Moni et al. [34], Dhas et al. [44], and Motshakeri et al. [53] successfully proved that Sargassum extract could improve inflammatory conditions in the diabetic rat model, but information about cellular mechanisms is still not obvious.

There are few researchers still using a protein denaturation inhibition model to screen anti-inflammatory activity in this new prostaglandin era. The reason behind choosing this model is based on the parallelism between two physio-pathological phenomena, namely inflammation and 
protein denaturation, both of which can be caused by the same stimulants (e.g., heat, radiation, organic solvents, etc.) [176]. Various types of NSAIDs (non-steroidal anti-inflammatory drugs) are reported to inhibit the in vitro denaturation of biologically active plasma proteins [177]. Protein denaturation can be the initial stage of further protein modification-for instance, protein glycosylation. Abnormal protein glycosylation phenomena occur frequently in chronic inflammatory diseases [178]. Nevertheless, the protein denaturation model is less convincing for most researchers today because the protein denaturation experiment is applied by mild heating $\left(47-50^{\circ} \mathrm{C}\right)$, which is not physiological. The implementation of the RBC membrane stabilization model for anti-inflammatory screening is based on the structural similarity between RBC and lysosome membranes. Lysosomes are important organelles that elicit the effectors mechanism in a late inflammatory response through releasing bactericidal enzymes and various proteinases, thereby maintaining their structural integrity is important for suppressing the inflammatory process [43].

Ten out of 18 studies on the anti-inflammatory activity of Sargassum's CSP utilized tropical species [97,99,101,105,107-109,111-113]. Preetha and Devaraj [99] reported that subcutaneous administration of $S$. wightii CSP improved high cholesterol diet-induced hypercholesterolemia in rats, manifested by the improvement of the plasma lipid profile, decreased serum TNF- $\alpha$, CRP, and plasma fibrinogen, the decreased cardiac mRNA expression of iNOS and COX-2, and the suppression of lysosomal enzymes and cardiac NO production. Fernando et al. [108] studied the effects of CSP from S. polycystum (SPF) in LPS-induced RAW 264.7 cells. They found that SPF treatment $(25-100 \mu \mathrm{g} / \mathrm{mL})$ reduced NO production, suppressed the expression of iNOS and COX-2 proteins, and increased cell viability. Furthermore, SPF reduced the production of $\mathrm{PGE}_{2}$ and some pro-inflammatory cytokines, including TNF- $\alpha$, IL-1 $\beta$, and IL-6. Lavanya et al. [105] observed the effect of CSP from S. ilicifolium (SIF) in TPA-induced polymorphonuclear leukocytes (PMNL). They reported that the SIF treatment increased the viability of PMNL cells and reduced the production of cathepsin D (lysosomal enzyme), nitrite, and TNF- $\alpha$. Information on the effects of SP from tropical Sargassum on inflammatory conditions is more profound than that in the previous section (the crude extract). This is because some researchers have tried to uncover the anti-inflammatory effects on cell units, and have used diverse inflammatory parameters to explain the effects between parameters in improving inflammatory conditions.

Alongside the trends occurring in crude extract screening studies, studies on the anti-inflammatory activity of Sargassum purified compounds are still dominated by subtropical samples $[19,27,65,108,116-134,137,140-143,145,147]$. Studies on the anti-inflammatory activity of tropical Sargassum purified compounds were carried out by Fernando et al. [26], Maneesh and Chakraborty [136,144], Sarithakumari et al. [138], and Sarithakumari and Kurup [139]. The tested pure compounds of tropical Sargassum were fucosterol, pure fucoidan/sulfated polygalactopyranosylfucopyranan, aryl polyketide lactones, and alginic acid. Maneesh and Chakraborty $[136,144]$ used an inhibition model of 5-LOX, COX-2, and COX-1 enzymes. Sarithakumari et al. [138] and Sarithakumari and Kurup [139] utilized the rat arthritis model to study the anti-inflammatory activity of alginic acid. Fernando et al. [26] reported that fucosterol isolated from S. binderi showed satisfactory anti-inflammatory activity in China fine dust particular matter (CPM)-induced A459 human lung epithelial cells, indicated by the suppression of COX-2 activity, decreased production of TNF- $\alpha$, IL-6, and PGE 2 , inhibition of NF-kB nuclear translocation, and inhibition of MAPK protein phosphorylation. The opportunity to discover the pure bioactive compounds from tropical Sargassum is still open, both for the type of unprecedented active compounds and the type of model to be selected, especially the model that can comprehensively explain inflammatory modulation.

\subsection{Potential Anti-Inflammatory Compounds of Tropical Sargassum}

Based on the literature summaries in Tables 1-4, polar and non-polar compounds of both tropical and subtropical Sargassum showed promising anti-inflammatory activity in various screening models. Various non-polar compounds from brown seaweed, which are thought to be responsible anti-inflammatory agents include sterol/terpenoids, omega-3 PUFAs, fucoxanthin and its derivatives, 
grasshopper ketone, and the polyketide group, while the water-soluble anti-inflammatory agents from Sargassum are sulfated polysaccharides, alginic acid, $\beta$-glucan, and phenolic components.

\subsubsection{Lipid-Soluble Bioactive Compounds}

The total lipid content in brown seaweed (the Sargassaceae family) is commonly higher in subtropical species $(-5 \% \mathrm{db})$ than in tropical species $(0.8 \%-1.9 \% \mathrm{db})$ [15]. However, high lipid levels $(-8 \% \mathrm{db})$ were found in tropical S. wightii harvested from Tamil Nadu, Gulf of Mannar, India [179]. The PUFA content and n3:n6 ratio were also found to be higher in subtropical Sargassum $[14,150,180]$. This could be related to environmental temperature differences. Low-temperature conditions in the subtropical region, especially in winter and fall, can cause an increase of PUFA concentrations in cell membranes, thereby implying the continuity of metabolic processes [181]. Although the PUFA content and n3:n6 ratio in tropical species are lower than those in subtropical ones, the n6:n3 ratio of tropical Sargassum still meets World Health Organization (WHO) recommendations (i.e., below 10). Maintaining its ratio in the recommended range can lower the human body's risk of inflammation-associated diseases, such as cardiovascular and neurological diseases.

Susanto et al. [14] showed that the fucoxanthin level of tropical Sargassum $(1.64 \pm 0.49 \mathrm{mg} / \mathrm{g} \mathrm{db})$ was not significantly different from that of subtropical Sargassum (1.99-2.12 mg/g db), although there was a higher amount in subtropical Sargassum. The fucoxanthin content of seaweed is strongly influenced by species, season, and maturity level [32,182,183]. Lann et al. [184] hypothesized that fucoxanthin in tropical Sargassaceae not only acts as an accessory light-harvesting pigment but also as a photoprotectant. High UV intensity in the tropical area will trigger the formation of free radicals in plant cells, so a certain defense mechanism is required to maintain cell structure integrity.

There is a lack of information on the effects of different latitudes (for tropical and subtropical areas) on the sterol content of Sargassum. Terasaki et al. [181] reported that S. horneri fucosterol content was higher in winter and in deep water seaweed. This phenomenon is related to the seaweed's response in preserving cell membrane integrity at low temperatures and in suboptimal photosynthetic conditions. Fucosterol plays an important role in supporting liquid-ordered membrane phases and determining membrane integrity by balancing the liquid and non-liquid phases in plant cell membranes [185]. The content of fucosterol in the S. horneri harvested from some Japanese waters was in the range of $1.21 \%-3.21 \% \mathrm{db}$ [181], while Fleury et al. [186] showed that the S. furcatum fucosterol content harvested from the water area of Rio De Janeiro, Brazil only reached $0.08 \%$ wt.

\subsubsection{Water-Soluble Bioactive Compounds}

Polyphenol content is generally higher in subtropical seaweeds than in tropical ones [184]. However, some studies have proven the opposite $[187,188]$. Bolser and Hay [189] revealed that tropical seaweed is likely to form stronger chemical defenses to withstand the intense grazing activity of tropical herbivores. Tropical herbivores are known to be more active and diverse. Bolser and Hay [189] hypothesized that the strong chemical defense of seaweed would be manifested by a high content of secondary metabolites, including those of the polyphenol group. Based on these facts, latitude difference is not the only predictor that determines seaweed's phenolic content. Various factors affecting the phenolic content in seaweed are age and maturity, the surrounding ecosystem conditions, latitude, geomorphology, depth, irradiation, hydrodynamic conditions, seasons, and water nutrient levels [184]. Tropical Sargassum species, especially those growing on the water surface, are rich in low Mw phenolic content $(<2 \mathrm{kDa})$, which is attributed to their role as photoprotectants in plant cells [184]. Audibert et al. [190] showed that the phenolic fraction of brown seaweed Ascophyllum nodosum with $\mathrm{Mw}<2 \mathrm{kDa}$ had the most potent radical scavenging (ABTS assay) activity compared to the crude phenolic extract and other fractions with higher Mw, although its TPC (total phenolic content) was the lowest among the other fractions. This result indicates that the qualitative composition of the fraction determines its antioxidant activity. Audibert et al. [190] added that the Trolox equivalent antioxidant capacity/TEAC $(\mathrm{mmol} / \mathrm{l})$ of the fraction $<2 \mathrm{kDa}$ is 3.5 times more active than phloroglucinol and twice 
more active than quercetin. The antioxidant activity of an active component is often reported to be positively correlated with its anti-inflammatory activity [191-194].

The biological activity of sulfated polysaccharides (SP) from tropical Sargassum has been discussed more frequently than the activity of other compounds. This is due to the high yield potency of SP, which is essential for its commercial development. The FCSP yield of tropical Sargassum ranges from $2.16 \%$ to $7.15 \% \mathrm{db}$ [195-197]. This reported yield is higher than that of other anti-inflammatory compounds, such as sterols, fucoxanthin, omega-3 PUFAs, and phenolic components. Sulfated polysaccharides are also recognized as potential antioxidants $[136,195,198]$. Several factors affecting the FCSP content in seaweed include mechanical stress (the level of ocean current and waves), the level of maturity, season, salinity, and part of the thallus [199]. In addition to FCSPs, alginic acid has been reported to show promising anti-inflammatory activity $[138,139]$. Kokilam et al. [200] reported that the yield of alginic acid in S. wightii harvested from Gulf of Mannar, India (tropical) reached 21.71\%. Moreover, Aponte de Otaola et al. [201] found that the alginic acid content of several tropical Sargassum species (whole plant) originating from Puerto Rico area were in the range of $17.9 \%-20.3 \%$.

FCSPs and alginates are important components of the wall structures of algae cells. Both of these components play an important role in attaining the flexibility requirements for intertidal seaweed [201,202]. So et al. [203] compared the protective activity of fucoidan and alginic acid against oxidative stress, both in vitro and cellular systems. The results revealed that fucoidan showed stronger scavenging activity for $\mathrm{NO}$ and superoxide anions than that of alginic acid. Fucoidan was also reported to be more effective in inhibiting lipid peroxidation in APPH (2,2'-azobis(2-amidinopropane) dihydrochloride)-induced LLK-PK1 cells.

\section{Anti-Inflammatory Mechanisms of Bioactive Compounds of Sargassum}

Inflammation is characterized by some general parameters, such as the overproduction of pro-inflammatory cytokines (generally TNF- $\alpha$, IL-1 $\beta$, and IL6), NO, $\mathrm{PGE}_{2}$, and ROS. Increased NO production occurs along with the increased activity of the iNOS enzyme. This enzyme converts L-arginine to $\mathrm{NO}$ [11], while $\mathrm{PGE}_{2}$ is produced through cyclooxygenase-2 (COX-2) enzyme activity, using arachidonic acid as a substrate. Arachidonic acid (AA) is a dominant constituent of the phospholipid bilayer in cell membranes. AA is produced from phospholipase A2's activity against phospholipids. In addition to prostaglandin, the AA substrate can also be converted into pro-inflammatory leukotrienes by the lipoxygenase enzyme (LOX) [31]. Sargassum bioactive compounds have been reported to modulate inflammatory responses via inhibition of NF-kB transactivation, inhibition of the MAPK group's phosphorylation (which impacts the blocking of AP-1 protein translocation), direct NO scavenging, and direct inhibition of important pro-inflammatory enzymes, such as iNOS, COX-2, 5-LOX, and PLA2.

As discussed in the previous section, NF-kB and AP-1 are important proteins that regulate the transcription of various inflammatory-related genes. The inhibition of their activation suppresses inflammatory response. The downstream responses due to NF-kB and AP-1 transactivation are depicted in Figure 7. Adhesion molecules, such as ICAM-1 and VCAM-1, are typical markers of the vascular system's inflammation. These compounds help monocytes attach to vascular endothelial cells and promote the initial phase of atherogenesis. Chemoattractant compounds, such as MCP-1, are produced by inflamed cells to recruit various immune cells such as monocytes, macrophages, neutrophils, and eosinophils to the inflammation site [123]. The matrix metalloproteinase (MMP) plays a role in the regulation of transmigration, extravasation, and monocyte infiltration into inflammatory sites through extracellular matrix degradation [204]. The risk of cardiovascular disease could also be characterized by the increased production of fibrinogen. Fibrinogen is known as a coagulation factor protein and is involved in atherosclerosis processes [99]. Sarithakumari et al. [138] used various parameters to describe the inflammatory response in arthritic rats, and one of these parameters was the xanthine oxidase $(\mathrm{XO})$ enzyme. $\mathrm{XO}$ activity is associated with increased oxidative stress in cells. This enzyme is responsible for producing superoxide anion radicals and increasing lipid peroxidation [205]. 


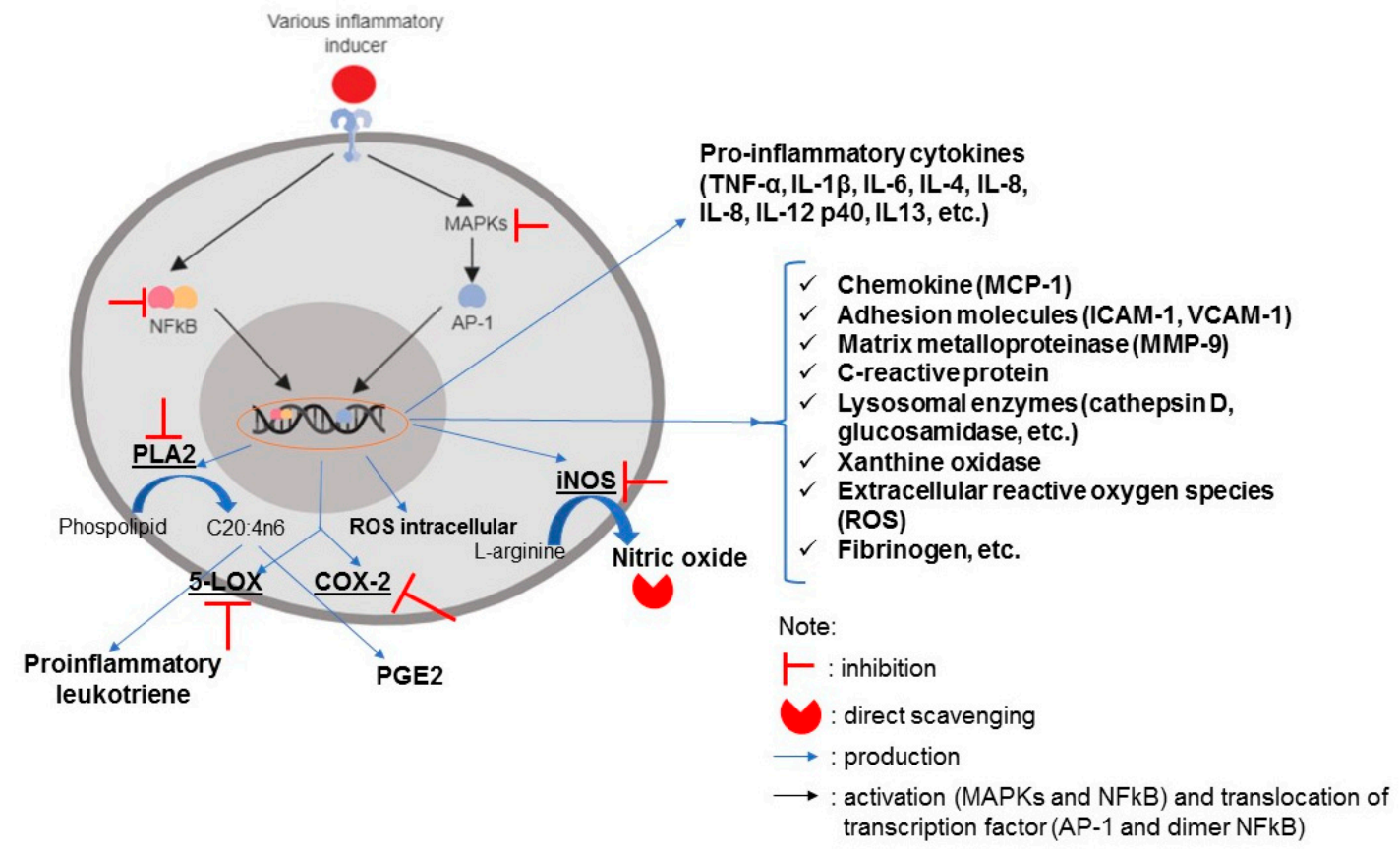

Figure 7. The inflammatory signaling pathway and the resulting downstream responses. Signs of and show the potential modulation of Sargassum bioactive compounds on the inflammatory response, including (1) the inhibition of NF-kB and MAPK activation, (2) the inhibition of pro-inflammatory enzymes PLA2, 5-LOX, COX-2, iNOS, and (3) the direct scavenging of radical species. This illustration was created by the author using Biorender.com.

The inhibition of NF-kB activation by Sargassum bioactive compounds (not only purified compounds, but also crude extracts and CSP) is proven by decreased phosphorylated NF-kB protein expression (p65 and/or p50), both in the nucleus and in cytoplasmic cell extracts $[26,37,75,123,132,135]$, as well as inhibition of phosphorylation and degradation of the IkB protein in the cytoplasmic extracts $[96,100,116,123,125,126,129,147]$. The Western blotting and ELISA methods are commonly used to see the expression of several of the aforementioned proteins. Confocal microscopy can also be used to visualize the expression of p-NF-kB through the immunofluorescence technique [129]. An NF-kB-dependent luciferase activity assay is able to monitor NF-kB binding into the DNA binding site $[83,132]$. Activation of the MAPK protein is usually indicated by levels of the phosphorylated MAPK protein (p38, JNK, and/or ERK1/2) in the cytoplasmic cell extract $[26,69,73,75,100,103,116,118,127-129,132,135,147]$ or by an AP-1-dependent luciferase activity assay [132]. Besides inhibiting NF-kB and MAPK group activation, the Sargassum bioactive compound (ethanolic extract of S. serratifolium) is reported to suppress PI3K (phosphatidylinositol 3 kinase) and Akt (protein kinase B) phosphorylation in IL-1 $\beta$-treated SW1353 chondrocytes. This phenomenon also relates to the improved inflammatory condition [68].

The modulation mechanism of the NF-kB signaling pathway used by Sargassum bioactive compounds is not yet clear. The presence of $\alpha-\beta$-unsaturated carbonyl groups in terpenoids is thought to be responsible, in part, for NF-kB inhibition because the methylene group can react with the sulfhydryl cysteine groups $\left(\mathrm{Cys}^{38}\right.$ and $\left.\mathrm{Cys}^{120}\right)$ located in the DNA binding domain of the p65 monomer (subunit NF-kB) [206]. Heras and Hortelano [153] summarized some specific mechanisms used in modulating the NF-kB signaling pathway by various terpenoid compounds: (1) Inhibition of IkB kinase (IKK) complex activation, (2) inhibition of proteasomal degradation on the IkB protein, and (3) blocking NF-kB nuclear translocation and/or NF-kB binding to the $\mathrm{kB}$ site. The most effective approach in NF-kB modulation is inhibition of the IKK complex's activation.

Some studies have revealed that Sargassum bioactive compounds can directly inhibit some pro-inflammatory enzymes, such as COX-2, COX-1, 5-LOX, PLA2, and hyaluronidase, via in vitro 
techniques $[39,136,144]$. The existence of electronegative functional groups, such as hydroxyl and methoxy, contained in Sargassum bioactive compounds is thought to be responsible for preventing the hydrogen abstraction from arachidonic acid in COX enzymes. Electronegative functionality also has the potential to coordinate the active site of COX/LOX enzymes through ion pairing, thereby preventing the biosynthesis of eicosanoid derivatives $[39,136]$. Electron-rich structures found in the macrolactone group, such as cyclic esters, the methyl acetate side chain, and vinyl or aryl substituents in the lactone ring, are reported to be positively correlated with the inhibition capacity on the COX-1, COX-2, and 5-LOX enzymes [144]. The reduction of NO concentration in inflamed cells or organisms could be caused by modulation of the upstream NO signaling pathway or direct $\mathrm{NO}$ scavenging by antioxidant compounds. Lopes et al. [143] reported that phlorotannin isolated from various species of brown seaweed, including $S$. vulgare, showed strong direct scavenging activity of Sodium nitroprusside (SNP)-generated NO in a cell-free system. This fact might contribute to the overall anti-inflammatory effect of phlorotannin in LPS-induced RAW 264.7 cells. Besides several aforementioned modulation mechanisms for Sargassum bioactive compounds, Chen et al. [207] proposed that maintaining the equilibrium state of the histone acetylation process as one type of post-translational modification can improve inflammation conditions. They reported that the Sargassum sp. polysaccharide extract treatment significantly inhibited the production of inflammatory cytokines and HAT (histone acetyltransferase) activity, but increased HDAC (histone deacetylase) activity and the mRNA expression of HDAC1 in porcine circovirus type 2 (PCV2)-infected RAW 264.7 cells.

Several other manifestations of the Sargassum's bioactive compounds against inflammatory conditions are include elevated intrinsic antioxidant activity (catalase, superoxide dismutase, glutathione peroxidase, and glutathione reductase) $[24,123,138]$, decreased production of ROS $[24,33,142]$, decreased pro-inflammatory cell population (T-helper, T-cytotoxic, granulocytes, eosinophils, and monocytes) [76], stabilization of the lysosomal membrane (which inhibits lysosomal enzymes, such as cathepsin D, glucosaminidase, glucuronidase, etc.) $[99,105,139]$, decreased edema volume and neutrophil infiltration in rat edema model [104], decreased production of osteoclastogenic factors (such as RANKL and osteoprotegerin in the IL-1 $\beta$-induced MG-63 osteoblast cells) [147], improvement of dyslipidemia conditions [50,99], and amelioration of insulin resistance [33,44]. Increased intrinsic antioxidant enzyme activity is associated with the increased expression of nuclear factor erythroid 2-related factor 2 (Nrf2) transcription factors, the responsible protein in cell defense mechanisms $[19,20,77,208]$. Lee et al. [209] found that the oral administration of fucosterol (30 mg/kg/ day for seven days) in $\mathrm{CCl}_{4}$-induced rat hepatotoxicity was able to improve the nuclear translocation of Nrf2. Related to the improvement of dyslipidemia, Preetha and Devaraj [99] hypothesized that CSP treatment in hypercholesterol diet-induced rats could delay cholesterol absorption in the intestine and might accelerate cholesterol excretion by modulating cholesterol-7-alpha-hydroxylase, a key enzyme for the conversion of cholesterol into bile acids.

Another mechanism that may be ascribed to the anti-inflammatory activity of Sargassum bioactive compounds is the interaction between active compounds and inflammatory-associated receptors, such as TLR4, CD14, CR-3, and SR-A. This interaction can interfere with the recognition of strong inflammatory stimuli by cells, e.g., LPS. The presence of sulfate groups in FCSPs is thought to affect its binding to inflammatory receptors $[169,210]$. Omega-3 fatty acids (especially SDA and EPA) in Sargassum may undergo incorporation into cell membranes and affect eicosanoid metabolism in cells. EPA and DHA can interfere with the activity of the COX-2 and 5-LOX enzymes against AA, so the production of strong pro-inflammatory $\mathrm{PGE}_{2}$ and $\mathrm{LT}_{4}$ can be inhibited [211]. Tian et al. [212] found that RAW 264.7 cell incubation with EPA, DHA, or DPA (docosapentaenoic acid) for $72 \mathrm{~h}$ suppressed the inflammatory response after LPS stimulation.

\section{Conclusions}

Sargassum is well-known to have beneficial effects on health and is traditionally utilized by the East Asian community to treat various inflammatory-related diseases. Various bioactive compounds of 
Sargassum show potential anti-inflammatory activity, both in acute and chronic conditions. The potency of tropical Sargassum as a source of the anti-inflammatory agent is not fully explored yet. Sulfated polysaccharides from tropical Sargassum are the most studied compounds for their anti-inflammatory activity. However, there are various other potentially bioactive compounds, such as non-polar compounds (fatty acids and derivatives, carotenoids and derivatives, steroids, and polar lipids), grasshopper ketone, polyketide macrolactone, and phenolic components. Bioactive compounds of Sargassum are reported to modulate the inflammatory response by inhibiting NF-kB and MAPK activation, direct inhibition of inflammation-associated enzymes, and direct scavenging of radical species. The information presented in this paper is expected to provide input for Sargassum development, especially its tropical species, as a source of anti-inflammatory agents.

Funding: This research received no external funding.

Acknowledgments: This review manuscript writing is a part of the sandwich-like program activity (Enhancing International Publication Program conducted at Universiti Putra Malaysia) funded by [Directorate General of Resources for Science, Technology and Higher Education, Ministry of Research, Technology and Higher Education, Republic of Indonesia] grant number [859/D3/PG/2019] and the APC was funded by Universiti Putra Malaysia.

Conflicts of Interest: The authors declare no conflict of interest.

\section{References}

1. Ahmed, A.U. An overview of inflammation: Mechanism and consequences. Front. Biol. China 2011, 6, 274-281.

2. Kotas, M.E.; Medzhitov, R. Homeostasis, inflammation, and disease susceptibility. Cell 2015, 160, 816-827. [CrossRef] [PubMed]

3. Medzhitov, R. Origin and physiological roles of inflammation. Nature 2008, 454, 428-435. [CrossRef] [PubMed]

4. Fernando, I.P.S.; Nah, J.-W.; Jeon, Y.-J. Potential anti-inflammatory natural products from marine algae. Environ. Toxicol. Pharmacol. 2016, 48, 22-30. [CrossRef]

5. Newton, K.; Dixit, V.M. Signaling in innate immunity and inflammation. Cold Spring Harb. Perspect. Biol. 2012, 4. [CrossRef]

6. Dray, A. Inflammatory mediators of pain. Br. J. Anaesth. 1995, 75, 125-131. [CrossRef]

7. Hotamisligil, G.S. Inflammation and metabolic disorders. Nature 2006, 444, 860-867. [CrossRef]

8. Fitton, J.H. Brown marine algae: A survey of therapeutic potentials. Altern. Complement. Ther. 2003, 9, 29-33. [CrossRef]

9. Oh, J.-H.; Kim, J.; Lee, Y. Anti-inflammatory and anti-diabetic effects of brown seaweeds in high-fat diet-induced obese mice. Nutr. Res. Pract. 2016, 10, 42. [CrossRef]

10. Husni, A.; Lailatussifa, R.; Isnansetyo, A. Sargassum hystrix as a source of functional food to improve blood biochemistry profiles of rats under stress. Prev. Nutr. Food Sci. 2019, 24, 150-158.

11. Vo, T.-S.; Ngo, D.-H.; Kim, S.-K. Potential targets for anti-inflammatory and anti-allergic activities of marine algae: An overview. Inflamm. Allergy-Drug Targets 2012, 11, 90-101. [CrossRef] [PubMed]

12. Liu, L.; Heinrich, M.; Myers, S.; Dworjanyn, S.A. Towards a better understanding of medicinal uses of the brown seaweed Sargassum in Traditional Chinese Medicine: A phytochemical and pharmacological review. J. Ethnopharmacol. 2012, 142, 591-619. [CrossRef] [PubMed]

13. Jaswir, I.; Monsur, H.A. Anti-inflammatory compounds of macro algae origin: A review. J. Med. Plants Res. 2011, 5, 7146-7154.

14. Susanto, E.; Fahmi, A.S.; Hosokawa, M.; Abe, M.; Miyashita, K. Lipids, fatty acids, and fucoxanthin content from temperate and tropical brown seaweeds. Aquat. Procedia 2016, 7, 66-75. [CrossRef]

15. Miyashita, K.; Mikami, N.; Hosokawa, M. Chemical and nutritional characteristics of brown seaweed lipids: A review. J. Funct. Foods 2013, 5, 1507-1517. [CrossRef]

16. Mattio, L.; Payri, C. Taxonomic revision of Sargassum species (Fucales, Phaeophyceae) from New Caledonia based on morphological and molecular. J. Phycol. 2009, 45, 374-1388. [CrossRef] 
17. Kantachumpoo, A.; Uwai, S.; Noiraksar, T.; Komatsu, T. Systematics of marine brown alga Sargassum from Thailand: A preliminary study based on morphological data and nuclear ribosomal internal transcribed spacer 2 (ITS2) sequences. Ocean Sci. J. 2015, 50, 251-262. [CrossRef]

18. Mun, O.J.; Kwon, M.S.; Karadeniz, F.; Kim, M.; Lee, S.H.; Kim, Y.Y.; Seo, Y.; Jang, M.S.; Nam, K.H.; Kong, C.S. Fermentation of Sargassum thunbergii by Kimchi-Derived Lactobacillus sp. SH-1 Attenuates LPS-Stimulated Inflammatory Response Via Downregulation of JNK. J. Food Biochem. 2017, 41, 1-9. [CrossRef]

19. Jayawardena, T.U.; Kim, H.S.; Sanjeewa, K.K.A.; Kim, S.Y.; Rho, J.R.; Jee, Y.; Ahn, G.; Jeon, Y.J. Sargassum horneri and isolated 6-hydroxy-4,4,7a-trimethyl-5,6,7,7a-tetrahydrobenzofuran-2(4H)-one (HTT); LPS-induced inflammation attenuation via suppressing NF- $\mathrm{KB}, \mathrm{MAPK}$ and oxidative stress through Nrf2/HO-1 pathways in RAW 264.7 macrophages. Algal Res. 2019, 40, 101513. [CrossRef]

20. Gwon, W.G.; Lee, S.G.; Kim, J., II; Kim, Y.M.; Kim, S.B.; Kim, H.R. Hexane fraction from the ethanolic extract of Sargassum serratifolium suppresses cell adhesion molecules via regulation of NF- $\mathrm{B}$ and Nrf2 pathway in human umbilical vein endothelial cells 06 Biological Sciences 0601 Biochemistry and Cell Biology. Fish. Aquat. Sci. 2019, 22, 1-10.

21. Yoon, W.J.; Ham, Y.M.; Lee, W.J.; Lee, N.H.; Hyun, C.G. Brown alga Sargassum muticum inhibits proinflammatory cytokines, iNOS, and COX-2 expression in macrophage RAW 264.7 cells. Turk. J. Biol. 2010, 34, 25-34.

22. Kang, J.Y.; Khan, M.N.A.; Park, N.H.; Cho, J.Y.; Lee, M.C.; Fujii, H.; Hong, Y.K. Antipyretic, analgesic, and anti-inflammatory activities of the seaweed Sargassum fulvellum and Sargassum thunbergii in mice. J. Ethnopharmacol. 2008, 116, 187-190. [CrossRef] [PubMed]

23. Dar, A.; Baig, H.S.; Saifullah, S.M.; Ahmad, V.U.; Yasmeen, S.; Nizamuddin, M. Effect of seasonal variation on the anti-inflammatory activity of Sargassum wightii growing on the N. Arabian Sea coast of Pakistan. J. Exp. Mar. Bio. Ecol. 2007, 351, 1-9. [CrossRef]

24. Lee, C.; Park, G.H.; Ahn, E.M.; Park, C.-I.; Jang, J.-H. Sargassum fulvellum protects HaCaT cells and BALB/c mice from UVB-induced proinflammatory responses. Evidence-Based Complement. Altern. Med. 2013, 2013, 1-10.

25. Kim, M.-J.; Kim, K.-B.-W.-R.; Jeong, D.-H.; Ahn, D.-H. Inhibitory effect of Sargauum fulvellum ethanolic extract on LPS-induced inflammatory reaction in RAW 264.7 mouse macrophages. J. Appl. Biol. Chem. 2013, 56, 249-255. [CrossRef]

26. Fernando, I.P.S.; Jayawardena, T.U.; Kim, H.S.; Lee, W.W.; Vaas, A.P.J.P.; De Silva, H.I.C.; Abayaweera, G.S.; Nanayakkara, C.M.; Abeytunga, D.T.U.; Lee, D.S.; et al. Beijing urban particulate matter-induced injury and inflammation in human lung epithelial cells and the protective effects of fucosterol from Sargassum binderi (Sonder ex J. Agardh). Environ. Res. 2019, 150-158. [CrossRef] [PubMed]

27. Jeon, H.; Yoon, W.J.; Ham, Y.M.; Yoon, S.A.; Kang, S.C. Anti-arthritis effect through the anti-inflammatory effect of Sargassum muticum extract in collagen-induced arthritic (CIA) Mice. Molecules 2019, $24,276$. [CrossRef] [PubMed]

28. Kwon, M.; Lim, S.J.; Joung, E.J.; Lee, B.; Oh, C.W.; Kim, H.R. Meroterpenoid-rich fraction of an ethanolic extract from Sargassum serratifolium alleviates obesity and non-alcoholic fatty liver disease in high fat-fed C57BL/6J mice. J. Funct. Foods 2018, 47, 288-298. [CrossRef]

29. Gwon, W.G.; Joung, E.J.; Shin, T.; Utsuki, T.; Wakamatsu, N.; Kim, H.R. Meroterpinoid-rich fraction of the ethanol extract from Sargassum serratifolium suppresses TNF- $\alpha$-induced monocytes adhesion to vascular endothelium and vascular inflammation in high cholesterol-fed C57BL/6J mice. J. Funct. Foods 2018, 46, 384-393. [CrossRef]

30. Karadeniz, F.; Lee, S.G.; Oh, J.H.; Kim, J.A.; Kong, C.S. Inhibition of MMP-2 and MMP-9 activities by solvent-partitioned Sargassum horneri extracts. Fish. Aquat. Sci. 2018, 21, 1-7. [CrossRef]

31. Sugiura, Y.; Kinoshita, Y.; Abe, M.; Murase, N.; Tanaka, R.; Matsushita, T.; Usui, M.; Hanaoka, K.; Miyata, M. Suppressive effects of the diethyl ether fraction from a brown alga Sargassum fusiforme on allergic and inflammatory reactions. Fish. Sci. 2016, 82, 369-377. [CrossRef]

32. Nomura, M.; Kamogawa, H.; Susanto, E.; Kawagoe, C.; Yasui, H.; Saga, N.; Hosokawa, M.; Miyashita, K. Seasonal variations of total lipids, fatty acid composition, and fucoxanthin contents of Sargassum horneri (Turner) and Cystoseira hakodatensis (Yendo) from the northern seashore of Japan. J. Appl. Phycol. 2013, 25, 1159-1169. [CrossRef] 
33. Han, Y.R.; Ali, M.Y.; Woo, M.H.; Jung, H.A.; Choi, J.S. Anti-Diabetic and Anti-Inflammatory Potential of the Edible Brown Alga Hizikia Fusiformis. J. Food Biochem. 2015, 39, 417-428. [CrossRef]

34. Moni, S.S.; Alam, M.F.; Makeen, H.A.; Jabeen, A.; Sanobar, S.; Siddiqui, R.; Moochikkal, R.; Fouda, S. Therapeutic potential of oleic acid nanovesicles prepared from petroleum ether extract of Sargassum binderi in streptozotocin-induced diabetic wound in wistar rats. Trop. J. Pharm. Res. 2018, 17, 2123-2128. [CrossRef]

35. Jaswir, I.; Monsur, H.A.; Simsek, S.; Amid, A.; Alam, Z.; Salleh, M.N.b.; Tawakalit, A.-H.; Octavianti, F. Cytotoxicity and inhibition of nitric oxide in lipopolysaccharide-induced mammalian cell lines by aqueous extracts of brown seaweed. J. Oleo Sci. 2014, 63, 787-794. [CrossRef]

36. Monsur, A.H.; Jaswir, I.; Simsek, S.; Amid, A.; Alam, Z.; Tawakalit, A.-H. Cytotoxicity and inhibition of nitric oxide syntheses in LPS induced macrophage by water soluble fractions of brown seaweed. Food Hydrocoll. 2014, 42, 269-274. [CrossRef]

37. Kim, M.; Kim, K.; Park, S.; Choi, H.; Park, S.; Kim, J.; Jang, M.; Im, M.; Ahn, D. Anti-Inflammatory effect of Sargassum patens C. Agardh ethanol extract in LPS-induced RAW264.7 cells and mouse ear edema. Korean J. Microbiol. Biotechnol. 2017, 45, 110-117. [CrossRef]

38. Kim, K.-N.; Kim, J.; Yoon, W.-J.; Yang, H.-M.; Heo, S.Y.; Ko, J.-Y.; Woon Roh, S.; Jeon, Y.-J.; Kang, S.-M.; Heo, S.-J.; et al. Inhibitory effect of Sargassum patens on inflammation and melanogenesis. Int. J. Pharmacol. 2013, 9, 524-532. [CrossRef]

39. Maneesh, A.; Chakraborty, K.; Makkar, F. Pharmacological activities of brown seaweed Sargassum wightii (Family Sargassaceae) using different in vitro models. Int. J. Food Prop. 2017, 20, 931-945. [CrossRef]

40. Fazeela, M.B.S.; Hemalatha, S. Characterisation, in silico and in vitro determination of antidiabetic and anti inflammatory potential of ethanolic extract of Sargassum wightii. Asian J. Pharm. Clin. Res. 2017, 10, $297-301$.

41. Raman, R.; Parthiban, S.; Karthikeyan, S.; Muthuraman, M.S.; Sivasubramanian, A. Antimicrobial and anti-inflammatory studies on Sargassum wightii extracts. Int. J. Pharm. Pharm. Sci. 2014, 6, 614.

42. Radhika, D.; Veerabahu, C.; Priya, R. Anti-inflammatory activities of some seaweed collected from The Gulf of Mannar Coast, Tuticorin, South India. Int. J. Pharma Bio Sci. 2013, 4, 39-44.

43. Pramitha, V.S.; Kumari, N.S. Anti-inflammatory, anti-oxidant, phytochemical, and GC-MS analysis of marine brown macroalga, Sargassum wightii. Int. J. Pharm. Chem. Biol. Sci. 2016, 6, 7-15.

44. Dhas, T.S.; Kumar, V.G.; Karthick, V.; Vasanth, K.; Singaravelu, G.; Govindaraju, K. Effect of biosynthesized gold nanoparticles by Sargassum swartzii in alloxan induced diabetic rats. Enzyme Microb. Technol. 2016, 95, 100-106. [CrossRef]

45. Hong, D.D.; Hien, H.M.; Anh, H.T.L. Studies on the analgesic and anti-inflammatory activities of Sargassum swartzii (Turner) C. Agardh (Phaeophyta) and Ulva reticulata Forsskal (Chlorophyta) in experiment animal models. African J. Biotechnol. 2011, 10, 2308-2313.

46. Khouzani, M.R.M.; Shushizadeh, M.R.; Kalantari, H.; Ghotrami, E.R. Hepatoprotective effect of aqueous extract of Persian Gulf brown algae Sargassum swartzii against acetaminophen-induced hepatotoxicity in mice. Jundishapur J. Nat. Pharm. Prod. 2019, 14, e77168.

47. Vairappan, C.S.; Kamada, T.; Lee, W.W.; Jeon, Y.-J. Anti-inflammatory activity of halogenated secondary metabolites of Laurencia snackeyi (Weber-van Bosse) Masuda. J. Appl. Phycol. 2013. [CrossRef]

48. Chamidah, A.; Prihanto, A.A.; Hardoko, H. Edema-reducing activity of Sargassum crassifolium B-glucan (laminaran) on edema-induced Rattus norvegicus. Asian J. Pharm. Clin. Res. 2017, 10, 311. [CrossRef]

49. Simpi, C.; Nagathan, C.; Karajgi, S.; Kalyane, N. Evaluation of marine brown algae Sargassum ilicifolium extract for analgesic and anti-inflammatory activity. Pharmacognosy Res. 2013, 5, 146. [CrossRef]

50. Ahmed, H.H.; Abdalla, M.S.; Eskander, E.F.; Al-Khadragy, M.F.; Massoud, M.N. Hypolipidemic influence of Sargassum subrepandum: Mechanism of action. Eur. Rev. Med. Pharmacol. Sci. 2012, 16, 112-120.

51. Buwono, N.R.; Risjani, Y.; Arsad, S. Anti-inflammatory and analgesic activity from brown algae Sargassum polycystum. J. Pharm. Sci. Res. 2018, 10, 2092-2096.

52. Raghavendran, H.B.; Sathivel, A.; Devaki, T. Defensive nature of Sargassum polycystum (Brown alga) against acetaminophen-induced toxic hepatitis in rats: Role of drug metabolizing microsomal enzyme system, tumor necrosis factor- $\alpha$ and fate of liver cell structural integrity. World J. Gastroenterol. 2006, 12, 3829-3834. [CrossRef] [PubMed]

53. Motshakeri, M.; Ebrahimi, M.; Goh, Y.M.; Othman, H.H.; Hair-bejo, M.; Mohamed, S. Effects of brown seaweed (Sargassum polycystum) extracts on kidney, liver, and pancreas of type 2 diabetic rat model. Evid.-Based Complement. Altern. Med. 2014, 2014, 379407. [CrossRef] 
54. Gany, S.A.; Tan, S.C.; Gan, S.Y. Anti-neuroinflammatory properties of Malaysian brown and green seaweeds. Int. J. Ind. Manuf. Eng. 2014, 8, 1269-1275.

55. Chatter, R.; Tarhouni, S.; Kharrat, R. Screening of anti-inflammatory and analgesic activities in marines macroalgae from Mediterranean Sea. Arch. Inst. Pasteur Tunis 2011, 88, 19-28.

56. Shreadah, M.A.; Abd, N.M.; Moneam, E. Phytochemical and pharmacological screening of Sargassium vulgare from Suez Canal, Egypt. Food Sci. Biotechnol. 2018, 27, 963-979. [CrossRef]

57. Yang, E.-J.; Moon, J.-Y.; Kim, M.-J.; Kim, D.S.; Kim, C.-S.; Lee, W.J.; Lee, N.H.; Hyun, C.-G. Inhibitory effect of Jeju endemic seaweeds on the production of pro-inflammatory mediators in mouse macrophage cell line RAW 264.7. J. Zhejiang Univ. Sci. B 2010, 11, 315-322. [CrossRef]

58. Lee, S.; Kang, H. Neuroprotective Effect of Sargassum thunbergii (Mertens ex Roth) Kuntze in Activated Murine Microglial Cells. Trop. J. Pharm. Res. 2015, 14, 235.

59. Kim, J.; Karadeniz, F.; Ahn, B.; Kwon, M.S.; Mun, O.; Kim, M.; Lee, S.; Yu, K.H.; Kim, Y.Y.; Kong, C. Sargassum sp. attenuates oxidative stress and suppresses lipid accumulation in vitro. J. Life Sci. 2014, 24, 274-283. [CrossRef]

60. Kim, J.; Kong, C.; Seo, Y.; Kim, S. Sargassum thunbergii extract inhibits MMP-2 and -9 expressions related with ROS scavenging in HT1080 cells. Food Chem. 2010, 120, 418-425. [CrossRef]

61. Khan, M.N.; Choi, J.; Lee, M.C.; Kim, E.; Nam, T.; Fujii, H.; Hong, Y.K. Anti-inflammatory activities of methanol extracts from various seaweed species. J. Environ. Biol. 2008, 29, 465-469.

62. Kim, J.; Kong, C.; Kim, S. Effect of Sargassum thunbergii on ROS mediated oxidative damage and identification of polyunsaturated fatty acid components. Food Chem. Toxicol. 2010, 48, 1243-1249. [CrossRef] [PubMed]

63. Gwon, W.-G.; Lee, M.-S.; Kim, J.-S.; Kim, J.-I.; Lim, C.-W.; Kim, N.-G.; Kim, H.-R. Hexane fraction from Sargassum fulvellum inhibits lipopolysaccharide-induced inducible nitric oxide synthase expression in RAW 264.7 cells via NF-kB pathways. Am. J. Chin. Med. 2013, 41, 565-584. [CrossRef] [PubMed]

64. Jeong, D.-H.; Kim, K.-B.-W.-R.; Kim, M.-J.; Kang, B.-K.; Bark, S.-W.; Pak, W.-M.; Kim, B.-R.; Ahn, N.-K.; Choi, Y.-U.; Ahn, D.-H. Anti-inflammatory effect of ethanol extract from Sargassum fulvellum on lipopolysaccharide induced inflammatory responses in RAW 264.7 cells and mice ears. J. Korean Soc. Food Sci. Nutr. 2014, 43, 1158-1165. [CrossRef]

65. Kang, B.; Kim, M.; Kim, K.; Ahn, D. In vivo and in vitro inhibitory activity of an ethanolic extract of Sargassum fulvellum and its component grasshopper ketone on atopic dermatitis. Int. Immunopharmacol. 2016, 40, 176-183. [CrossRef] [PubMed]

66. Joung, E.-J.; Gwon, W.-G.; Shin, T.; Jung, B.-M.; Choi, J.; Kim, H.-R. Anti-inflammatory action of the ethanolic extract from Sargassum serratifolium on lipopolysaccharide-stimulated mouse peritoneal macrophages and identification of active components. J. Appl. Phycol. 2017, 29, 563-573. [CrossRef]

67. Oh, S.-J.; Joung, E.-J.; Kwon, M.-S.; Lee, B.; Utsuki, T.; Oh, C.-W.; Kim, H.-R. Anti-Inflammatory Effect of Ethanolic Extract of Sargassum serratifolium in Lipopolysaccharide-Stimulated BV2 Microglial Cells. J. Med. Food 2016, 19, 1023-1031. [CrossRef] [PubMed]

68. Park, C.; Jeong, J.W.; Lee, D.S.; Yim, M.J.; Lee, J.M.; Han, M.H.; Kim, S.; Kim, H.S.; Kim, G.Y.; Park, E.K.; et al. Sargassum serratifolium extract attenuates interleukin- $1 \beta$-induced oxidative stress and inflammatory response in chondrocytes by suppressing the activation of NF-kB, p38 MAPK, and PI3K/Akt. Int. J. Mol. Sci. 2018, 19, 2308. [CrossRef]

69. Kim, M.-J.; Bae, N.-Y.; Kim, K.-B.-W.-R.; Park, S.-H.; Jang, M.-R.; Im, M.-H.; Ahn, D.H. Anti-inflammatory activity of ethanol extract of Sargassum miyabei Yendo via inhibition of NF-kB and MAPK activation. Microbiol. Biotechnol. Lett. 2016, 44, 442-451. [CrossRef]

70. Liu, N.; Fu, X.; Duan, D.; Xu, J.; Gao, X.; Zhao, L. Evaluation of bioactivity of phenolic compounds from the brown seaweed of Sargassum fusiforme and development of their stable emulsion. J. Appl. Phycol. 2018, 30, 1955-1970. [CrossRef]

71. Kang, S.y.; Kim, E.; Kang, I.; Lee, M.; Lee, Y. Anti-diabetic effects and anti-inflammatory effects of Laminaria japonica and hizikia fusiforme in skeletal muscle: In vitro and in vivo model. Nutrients 2018, 10, 491. [CrossRef] [PubMed]

72. Kwon, M.S.; Mun, O.; Bae, M.J.; Lee, S.; Kim, M.; Lee, S.; Yu, K.H.; Kim, Y.Y.; Kong, C. Anti-inflammatory activity of ethanol extracts from Hizikia fusiformis fermented with lactic acid bacteria in LPS-stimulated RAW264.7 macrophages. J. Korean Soc. Food Sci. Nutr. 2015, 44, 1450-1457. [CrossRef] 
73. Kim, M.E.; Jung, Y.C.; Jung, I.; Lee, H.-W.; Youn, H.-Y.; Lee, J.S. Anti-inflammatory Effects of Ethanolic Extract from Sargassum horneri (Turner) C. Agardh on Lipopolysaccharide-Stimulated Macrophage Activation via NF-кB Pathway Regulation. Immunol. Invest. 2015, 44, 137-146. [CrossRef] [PubMed]

74. Lee, S.B.; Lee, J.Y.; Song, D.; Pan, C.; Nho, C.W.; Kim, M.C.; Lee, E.H.; Jung, H.; Kim, H.; Kim, Y.S.; et al. Cancer chemopreventive effects of Korean seaweed extracts. Food Sci. Biotechnol. 2008, 17, 613-622.

75. Sanjeewa, K.K.A.; Jayawardena, T.U.; Kim, H.S.; Kim, S.Y.; Ahn, G.; Kim, H.J.; Fu, X.; Jee, Y.; Jeon, Y.J. Ethanol extract separated from Sargassum horneri (Turner) abate LPS-induced inflammation in RAW 264.7 macrophages. Fish. Aquat. Sci. 2019, 22, 1-10. [CrossRef]

76. Herath, K.H.I.N.M.; Cho, J.; Kim, A.; Kim, H.S.; Han, E.J.; Kim, H.J.; Kim, M.S.; Ahn, G.; Jeon, Y.J.; Jee, Y. Differential modulation of immune response and cytokine profiles of Sargassum horneri ethanol extract in murine spleen with or without Concanavalin A stimulation. Biomed. Pharmacother. 2019, 110, 930-942. [CrossRef]

77. Jayawardena, T.U.; Asanka Sanjeewa, K.K.; Shanura Fernando, I.P.; Ryu, B.M.; Kang, M.C.; Jee, Y.; Lee, W.W.; Jeon, Y.J. Sargassum horneri (Turner) C. Agardh ethanol extract inhibits the fine dust inflammation response via activating Nrf2/HO-1 signaling in RAW 264.7 cells. BMC Complement. Altern. Med. 2018, 18, 249. [CrossRef]

78. Kim, H.S.; Sanjeewa, K.K.A.; Fernando, I.P.S.; Ryu, B.; Yang, H.W.; Ahn, G.; Kang, M.C.; Heo, S.J.; Je, J.G.; Jeon, Y.J. A comparative study of Sargassum horneri Korea and China strains collected along the coast of Jeju island South Korea: Its components and bioactive properties. Algae 2018, 33, 341-349. [CrossRef]

79. Sanjeewa, K.K.A.; Fernando, I.P.S.; Kim, S.; Kim, W.; Jee, Y.; Jeon, Y. Ecklonia cava (Laminariales) and Sargassum horneri (Fucales) synergistically inhibit the lipopolysaccharide-induced inflammation via blocking NF-кB and MAPK pathways. Algae 2019, 34, 45-56. [CrossRef]

80. Kang, B.-K.; Kim, K.-B.-W.-R.; Kim, M.-J.; Bark, S.-W.; Pak, W.-M.; Ahn, N.-K.; Choi, Y.-U.; Bae, N.-Y.; Park, J.-H.; Ahn, D.-H. Anti-inflammatory effect of Sargassum coreanum ethanolic extract through suppression of NF-kB pathway in LPS induced RAW264.7 cells in mice. Microbiol. Biotechnol. Lett. 2015, 43, 112-119. [CrossRef]

81. Jeong, D.H.; Kang, B.K.; Kim, K.B.W.R.; Kim, M.J.; Ahn, D.H. Anti-inflammatory activity of Sargassum micracanthum water extract. J. Appl. Biol. Chem. 2014, 57, 227-234. [CrossRef]

82. Jeong, D.-H.; Kim, K.-B.-W.-R.; Kim, M.-J.; Kang, B.-K.; Ahn, D.-H. Anti-inflammatory activity of ethanolic extract of Sargassum micracanthum. J. Microbiol. Biotechnol. 2013, 23, 1691-1698. [CrossRef] [PubMed]

83. Manzoor, Z.; Mathema, V.B.; Chae, D.; Yoo, E.-S.; Kang, H.-K.; Hyun, J.-W.; Lee, N.H.; Ko, M.-H.; Koh, Y.-S. Extracts of the seaweed Sargassum macrocarpum inhibit the CpG-induced inflammatory response by attenuating the NF-kB pathway. Food Sci. Biotechnol. 2014, 23, 293-297. [CrossRef]

84. Cheon, J.M.; Kim, H.S.; Choi, E.O.; Kwon, D.H.; Choi, Y.H.; Kim, B.W.; Hwang, H.J. Anti-inflammatory activities of an ethanol extract of Sargassum macrocarpum in Lipopolysaccharide (LPS) stimulated RAW 264.7 macrophages. J. Life Sci. 2017, 27, 1437-1444.

85. Kim, M.-J.; Kim, K.-B.-W.-R.; Jeong, D.-H.; Ahn, D.-H. Anti-inflammatory activity of ethanolic extract of Sargassum sagamianum in RAW 264.7 cells. Food Sci. Biotechnol. 2013, 22, 1113-1120. [CrossRef]

86. Song, J.H.; Piao, M.J.; Han, X.; Kang, K.A.; Kang, H.K.; Yoon, W.J.; Ko, M.H.; Lee, N.H.; Lee, M.Y.; Chae, S.; et al. Anti-wrinkle effects of Sargassum muticum ethyl acetate fraction on ultraviolet B-irradiated hairless mouse skin and mechanistic evaluation in the human HaCaT keratinocyte cell line. Mol. Med. Rep. 2016, 14, 2937-2944. [CrossRef]

87. Safhi, M.M.; Alam, M.F.; Sivakumar, S.M.; Anwer, T. Hepatoprotective potential of Sargassum muticum against STZ-induced diabetic liver damage in wistar rats by inhibiting cytokines and the apoptosis pathway. Anal. Cell. Pathol. 2019, 2019, 7958701. [CrossRef]

88. Piao, M.J.; Kim, K.C.; Zheng, J.; Yao, C.W.; Cha, J.W.; Jin, S.; Yoon, W.J.; Kang, H.K.; Yoo, E.S.; Koh, Y.S.; et al. The ethyl acetate fraction of Sargassum muticum attenuates ultraviolet B radiation-induced apoptotic cell death via regulation of MAPK- and caspase-dependent signaling pathways in human HaCaT keratinocytes The ethyl acetate fraction of Sargassum muticum a. Pharm. Biol. 2014, 52, 1110-1118. [CrossRef]

89. Na, H.-J.; Moon, P.-D.; Ko, S.-G.; Lee, H.-J.; Jung, H.-A.; Hong, S.-H.; Seo, Y.; Oh, J.-M.; Lee, B.-H.; Choi, B.-W.; et al. Sargassum hemiphyllum inhibits atopic allergic reaction via the regulation of inflammatory mediators. J. Pharmacol. Sci. 2005, 97, 219-226. [CrossRef]

90. Shin, D.-B.; Han, E.-H.; Park, S.-S. Cytoprotective Effects of Phaeophyta Extracts from the Coast of Jeju Island in HT-22 Mouse Neuronal Cells. J. Korean Soc. Food Sci. Nutr. 2014, 43, 224-230. [CrossRef] 
91. Lee, S.; Lee, D.; Kim, M.; Kong, C.; Yu, K.; Kim, Y.; Lee, S. Enhancement of anti-inflammatory activity by fermentation of Sargassum siliquanstrum. J. Life Sci. 2016, 26, 318-324. [CrossRef]

92. Zhang, R.; Luo, W.; Bi, T.; Zhou, S. Evaluation of Antioxidant and Immunity-Enhancing Activities of Sargassum pallidum Aqueous Extract in Gastric Cancer Rats. Molecules 2012, 17, 8419-8429. [CrossRef]

93. Balachandran, P.; Parthasarathy, V.; Ajay Kumar, T.V. Isolation of Compounds from Sargassum wightii by GCMS and the Molecular Docking against Anti-Inflammatory Marker COX2. Int. Lett. Chem. Phys. Astron. 2016, 63, 1-12. [CrossRef]

94. Brglez Mojzer, E.; Knez Hrnčič, M.; Škerget, M.; Knez, Ž.; Bren, U. Polyphenols: Extraction methods, antioxidative action, bioavailability and anticarcinogenic effects. Molecules 2016, 21, 901. [CrossRef]

95. Liu, L.; Jin, C.; Zhang, Y. Lipophilic phenolic compounds (Lipo-PCs): Emerging antioxidants applied in lipid systems. RSC Adv. 2014, 4, 2879-2891. [CrossRef]

96. Sanjeewa, K.K.A.; Fernando, I.P.S.; Kim, S.Y.; Kim, H.S.; Ahn, G.; Jee, Y.; Jeon, Y.J. In vitro and in vivo anti-inflammatory activities of high molecular weight sulfated polysaccharide; containing fucose separated from Sargassum horneri: Short communication. Int. J. Biol. Macromol. 2018, 107, 803-807. [CrossRef]

97. Dore, C.M.P.G.; Faustino Alves, M.G.D.C.; Pofírio Will, L.S.E.; Costa, T.G.; Sabry, D.A.; De Souza Rêgo, L.A.R.; Accardo, C.M.; Rocha, H.A.O.; Filgueira, L.G.A.; Leite, E.L. A sulfated polysaccharide, fucans, isolated from brown algae Sargassum vulgare with anticoagulant, antithrombotic, antioxidant and anti-inflammatory effects. Carbohydr. Polym. 2013, 91, 467-475. [CrossRef]

98. Hwang, P.-A.; Chien, S.-Y.; Chan, Y.-L.; Lu, M.-K.; Wu, C.-H.; Kong, Z.-L.; Wu, C.-J. Inhibition of lipopolysaccharide (LPS)-induced inflammatory responses by Sargassum hemiphyllum sulfated polysaccharide extract in RAW 264.7 macrophage cells. J. Agric. Food Chem. 2011, 59, 2062-2068. [CrossRef]

99. Preetha, S.P.; Devaraj, H. Role of sulphated polysaccharides from Sargassum wightii in the control of diet-induced hyperlipidemia and associated inflammatory complications in rats. Eur. J. Inflamm. 2010, 8, 23-30. [CrossRef]

100. Sanjeewa, K.K.A.; Fernando, I.P.S.; Kim, E.-A.; Ahn, G.; Jee, Y.; Jeon, Y.-J. Anti-inflammatory activity of a sulfated polysaccharide isolated from an enzymatic digest of brown seaweed Sargassum horneri in RAW 264.7 cells. Nutr. Res. Pract. 2017, 11, 3-10. [CrossRef]

101. Neelakandan, Y.; Venkatesan, A. Antinociceptive and anti-inflammatory effect of sulfated polysaccharide fractions from Sargassum wightii and Halophila ovalis in male Wistar rats. Indian J. Pharmacol. 2016, 48, 562. [CrossRef]

102. Wen, Z.-S.; Xiang, X.-W.; Jin, H.-X.; Guo, X.-Y.; Liu, L.-J.; Huang, Y.-N.; OuYang, X.-K.; Qu, Y.-L. Composition and anti-inflammatory effect of polysaccharides from Sargassum horneri in RAW264.7 macrophages. Int. J. Biol. Macromol. 2016, 88, 403-413. [CrossRef]

103. Wu, G.J.; Shiu, S.M.; Hsieh, M.C.; Tsai, G.J. Anti-inflammatory activity of a sulfated polysaccharide from the brown alga Sargassum cristaefolium. Food Hydrocoll. 2016, 53, 16-23. [CrossRef]

104. Hwang, P.-A.; Hung, Y.-L.; Chien, S.-Y. Inhibitory activity of Sargassum hemiphyllum sulfated polysaccharide in arachidonic acid-induced animal models of inflammation. J. Food Drug Anal. 2015, 23, 49-56. [CrossRef]

105. Lavanya, R.; Seethalakshmi, S.; Gopal, V.; Chamundeeswari, D. Effect of crude sulphated polysaccharide from marine brown algae in TPA induced inflammation on poly morphonuclear leukocytes. Int. J. Pharm. Pharm. Sci. 2015, 7, 100-102.

106. Raafat, E.M.; Gamal-Eldeen, A.M.; El-Hussieny, E.A.; Ahmed, E.F.; Eissa, A.A. Polysaccharide extracts of the brown alga Sargassum asperifolium possess in vitro cancer chemopreventive properties. Nat. Prod. Res. 2014, 28, 2304-2311. [CrossRef]

107. Neelakandan, Y.; Kanmani, P.; Satishkumar, R.; Paari, A.; Pattukumar, V.; Arul, V. Antinociceptive and Anti-Inflammatory activities of Sargassum wightii and Halophila ovalis sulfated polysaccharides in experimental animal models. J. Med. Food 2013, 16, 740-748.

108. Fernando, I.P.S.; Asanka Sanjeewa, K.K.; Samarakoon, K.W.; Kim, H.-S.; Gunasekara, U.K.D.S.S.; Park, Y.-J.; Abeytunga, D.T.U.; Lee, W.W.; Jeon, Y.-J. The potential of fucoidans from Chnoospora minima and Sargassum polycystum in cosmetics: Antioxidant, anti-inflammatory, skin-whitening, and antiwrinkle activities. J. Appl. Phycol. 2018, 30, 3223-3232. [CrossRef]

109. Fernando, I.P.S.; Sanjeewa, K.K.A.; Samarakoon, K.W. Antioxidant and anti-inflammatory functionality of ten Sri Lankan seaweed extracts obtained by carbohydrase assisted extraction. Food Sci. Biotechnol. 2018, 27, 1761-1769. [CrossRef] 
110. Gamal-Eldeen, A.M.; Ahmed, E.F.; Abo-Zeid, M.A. In vitro cancer chemopreventive properties of polysaccharide extract from the brown alga, Sargassum latifolium. Food Chem. Toxicol. 2009, 47, 1378-1384. [CrossRef]

111. Vasquez, R.D.; Garcia-Meim, R.S.; Ramos, J.D.A. Polysaccharide extract from Sargassum siliquosum J.G. Agardh modulates production of pro-inflammatory cytokines in LPS-induced PBMC and delays coagulation time in-vitro. J. Harmon. Res. Pharm. 2014, 3, 101-112.

112. Vasquez, R.D.; Ramos, J.D.A. Immunomodulatory effects of sulfated polysaccharides from Sargassum siliquosum J.G Agardh on peripheral blood mononuclear cells. Int. J. Res. Phytochem. Pharmacol. 2012, 22, 55-63.

113. Vasquez, R.D.; Ramos, J.D.A.; Bernal, S.D. Chemopreventive properties of sulfated polysaccharide extracts from Sargassum siliquosum J.G. Agardh (Sargassaceae). Int. J. Pharma Bio Sci. 2012, 3, 333-345.

114. Senni, K.; Gueniche, F.; Foucault-Bertaud, A.; Igondjo-Tchen, S.; Fioretti, F.; Colliec-Jouault, S.; Durand, P.; Guezennec, J.; Godeau, G.; Letourneur, D. Fucoidan a sulfated polysaccharide from brown algae is a potent modulator of connective tissue proteolysis. Arch. Biochem. Biophys. 2006, 445, 56-64. [CrossRef]

115. Deniaud-Bouët, E.; Hardouin, K.; Potin, P.; Kloareg, B.; Hervé, C. A review about brown algal cell walls and fucose-containing sulfated polysaccharides: Cell wall context, biomedical properties and key research challenges. Carbohydr. Polym. 2017, 175, 395-408. [CrossRef]

116. Yoon, W.-J.; Heo, S.-J.; Han, S.-C.; Lee, H.-J.; Kang, G.-J.; Kang, H.-K.; Hyun, J.-W.; Koh, Y.-S.; Yoo, E.-S. Anti-inflammatory effect of sargachromanol G isolated from Sargassum siliquastrum in RAW 264.7 cells. Arch. Pharm. Res. 2012, 35, 1421-1430. [CrossRef]

117. Heo, S.-J.; Yoon, W.-J.; Kim, K.-N.; Oh, C.; Choi, Y.-U.; Yoon, K.-T.; Kang, D.-H.; Qian, Z.-J.; Choi, I.-W.; Jung, W.-K. Anti-inflammatory effect of fucoxanthin derivatives isolated from Sargassum siliquastrum in lipopolysaccharide-stimulated RAW 264.7 macrophage. Food Chem. Toxicol. 2012, 50, 3336-3342. [CrossRef]

118. Lee, J.-H.; Ko, J.-Y.; Samarakoon, K.; Oh, J.-Y.; Heo, S.-J.; Kim, C.-Y.; Nah, J.-W.; Jang, M.-K.; Lee, J.-S.; Jeon, Y.-J. Preparative isolation of sargachromanol E from Sargassum siliquastrum by centrifugal partition chromatography and its anti-inflammatory activity. Food Chem. Toxicol. 2013, 62, 54-60. [CrossRef]

119. Jeon, Y.; Jung, Y.; Cheol, M.; Cheol, H.; Sung, K.; Kee, Y.; Kim, S. Sargahydroquinoic acid inhibits TNF a -induced AP-1 and NF-kB signaling in HaCaT cells through PPAR a activation. Biochem. Biophys. Res. Commun. 2014, 450, 1553-1559. [CrossRef]

120. Kim, J.; Ahn, B.; Kong, C.; Kim, S. Protective effect of chromene isolated from Sargassum horneri against UV-A-induced damage in skin dermal fibroblasts. Exp. Dermatol. 2012, 21, 630-631. [CrossRef]

121. Fernando, P.; Piao, M.J.; Hewage, S.; Kang, H.K.; Yoo, E.S.; Koh, Y.S.; Ko, M.H.; Ko, C.S.; Byeon, S.H.; Mun, S.R.; et al. Photo-protective effect of sargachromenol against UVB radiation-induced damage through modulating cellular antioxidant systems and apoptosis in human keratinocytes. Environ. Toxicol. Pharmacol. 2016, 43, 112-119. [CrossRef]

122. Kim, E.A.; Kim, S.Y.; Kim, J.; Oh, J.Y.; Kim, H.S.; Yoon, W.J.; Kang, D.H.; Heo, S.J. Tuberatolide B isolated from Sargassum macrocarpum inhibited LPS-stimulated inflammatory response via MAPKs and NF-KB signaling pathway in RAW264.7 cells and zebrafish model. J. Funct. Foods 2019, 52, 109-115. [CrossRef]

123. Gwon, W.-G.; Joung, E.-J.; Kwon, M.-S.; Lim, S.-J.; Utsuki, T.; Kim, H.-R. Sargachromenol protects against vascular inflammation by preventing TNF- $\alpha$-induced monocyte adhesion to primary endothelial cells via inhibition of NF- $\mathrm{kB}$ activation. Int. Immunopharmacol. 2017, 42, 81-89. [CrossRef]

124. Gwon, W.-G.; Lee, B.; Joung, E.-J.; Choi, M.-W.; Yoon, N.; Shin, T.; Oh, C.-W.; Kim, H.-R. Sargaquinoic acid inhibits TNF- $\alpha$-induced NF- $\mathrm{kB}$ signaling, thereby contributing to decreased monocyte adhesion to human umbilical vein endothelial cells (HUVECs). J. Agric. Food Chem. 2015, 63, 9053-9061. [CrossRef]

125. Ham, Y.M.; Yoon, W.J.; Lee, W.J.; Kim, S.C.; Baik, J.S.; Kim, J.H.; Lee, G.S.; Lee, N.H.; Hyun, C.G. Anti-inflammatory effects of isoketocharbroic acid from brown alga, Sargassum Micracanthum. EXCLI J. 2015, 14, 1116-1121.

126. Yang, E.-J.; Ham, Y.M.; Yang, K.-W.; Lee, N.H.; Hyun, C.-G. Sargachromenol from Sargassum micracanthum inhibits the lipopolysaccharide-induced production of inflammatory mediators in RAW 264.7 macrophages. Sci. World J. 2013, 2013, 1-6.

127. Heo, S.-J.; Jang, J.; Ye, B.-R.; Kim, M.-S.; Yoon, W.-J.; Oh, C.; Kang, D.-H.; Lee, J.-H.; Kang, M.-C.; Jeon, Y.-J.; et al. Chromene suppresses the activation of inflammatory mediators in lipopolysaccharide-stimulated RAW 264.7 cells. Food Chem. Toxicol. 2014, 67, 169-175. [CrossRef] 
128. Sah, S.K.; Kim, B.-H.; Park, G.-T.; Kim, S.; Hwa Jang, K.; Eun Jeon, J.; Shin, J.; Kim, T.-Y. Novel isonahocol E3 exhibits anti-inflammatory and anti-angiogenic effects in endothelin-1-stimulated human keratinocytes. Eur. J. Pharmacol. 2013, 720, 205-211. [CrossRef]

129. Kang, G.-J.; Han, S.-C.; Yoon, W.-J.; Koh, Y.-S.; Hyun, J.-W.; Kang, H.-K.; Youl Cho, J.; Yoo, E.-S. Sargaquinoic acid isolated from Sargassum siliquastrum inhibits lipopolysaccharide-induced nitric oxide production in macrophages via modulation of nuclear factor- $\mathrm{kB}$ and $\mathrm{c}-\mathrm{Jun} \mathrm{N}$-terminal kinase pathways. Immunopharmacol. Immunotoxicol. 2013, 35, 80-87. [CrossRef]

130. Kim, E.A.; Kim, S.Y.; Ye, B.R.; Kim, J.; Ko, S.C.; Lee, W.W.; Kim, K.N.; Choi, I.W.; Jung, W.K.; Heo, S.J. Anti-inflammatory effect of Apo-9'-fucoxanthinone via inhibition of MAPKs and NF-kB signaling pathway in LPS-stimulated RAW 264.7 macrophages and zebrafish model. Int. Immunopharmacol. 2018, 59, 339-346. [CrossRef]

131. Han, S.-C.; Kang, N.-J.; Yoon, W.-J.; Kim, S.; Na, M.-C.; Koh, Y.-S.; Hyun, J.-W.; Lee, N.-H.; Ko, M.-H.; Kang, H.-K.; et al. External application of apo-9-fucoxanthinone, isolated from Sargassum muticum, suppresses inflammatory responses in a mouse model of atopic dermatitis. Toxicol. Res. 2016, 32, 109-114. [CrossRef] [PubMed]

132. Chae, D.; Manzoor, Z.; Kim, S.; Kim, S.; Oh, T.-H.; Yoo, E.-S.; Kang, H.-K.; Hyun, J.-W.; Lee, N.; Ko, M.-H.; et al. Apo-9'-fucoxanthinone, isolated from Sargassum muticum, inhibits CpG-Induced inflammatory response by attenuating the mitogen-activated protein kinase pathway. Mar. Drugs 2013, 11, 3272-3287. [CrossRef] [PubMed]

133. Yang, E.-J.; Ham, Y.; Lee, W.; Lee, N.; Hyun, C.-G. Anti-inflammatory effects of apo-9'-fucoxanthinone from the brown alga, Sargassum muticum. DARU J. Pharm. Sci. 2013, 21, 62-68. [CrossRef] [PubMed]

134. Han, M.; Sun, P.; Li, Y.; Wu, G.; Nie, J. Structural characterization of a polysaccharide from Sargassum henslowianum, and its immunomodulatory effect on gastric cancer rat. Int. J. Biol. Macromol. 2018, 108, 1120-1127. [CrossRef]

135. Fernando, I.P.S.; Jayawardena, T.U.; Sanjeewa, K.K.A.; Wang, L.; Jeon, Y.-J.; Lee, W.W. Anti-inflammatory potential of alginic acid from Sargassum horneri against urban aerosol-induced inflammatory responses in keratinocytes and macrophages. Ecotoxicol. Environ. Saf. 2018, 160, 24-31. [CrossRef]

136. Maneesh, A.; Chakraborty, K. Pharmacological potential of sulfated polygalactopyranosyl-fucopyranan from the brown seaweed Sargassum wightii. J. Appl. Phycol. 2018, 30, 1971-1988. [CrossRef]

137. Hwang, P.A.; Phan, N.N.; Lu, W.J.; Hieu, B.T.N.; Lin, Y.C. Low-molecular-weight fucoidan and high-stability fucoxanthin from brown seaweed exert prebiotics and anti-inflammatory activities in Caco-2 cells. Food Nutr. Res. 2016, 60, 1-9. [CrossRef]

138. Sarithakumari, C.H.; Renju, G.L.; Kurup, G.M. Anti-inflammatory and antioxidant potential of alginic acid isolated from the marine algae, Sargassum wightii on adjuvant-induced arthritic rats. Inflammopharmacology 2013, 21, 261-268. [CrossRef]

139. Sarithakumari, C.H.; Kurup, G.M. Alginic acid isolated from Sargassum wightii exhibits anti-inflammatory potential on type II collagen induced arthritis in experimental animals. Int. Immunopharmacol. 2013, 17, 1108-1115. [CrossRef]

140. Sanjeewa, K.K.A.; Jayawardena, T.U.; Kim, S.; Kim, H.; Ahn, G.; Kim, J.; Jeon, Y. Fucoidan isolated from invasive Sargassum horneri inhibit LPS-induced inflammation via blocking NF-кB and MAPK pathways. Algal Res. 2019, 41, 1015611. [CrossRef]

141. Lin, H.V.; Tsou, Y.; Chen, Y.; Lu, W.; Hwang, P. Effects of low-molecular-weight fucoidan and high stability fucoxanthin on glucose homeostasis, lipid metabolism, and liver function in a mouse model of type II diabetes. Mar. Drugs 2017, 15, 113. [CrossRef] [PubMed]

142. Casas, M.P.; Rodríguez-Hermida, V.; Pérez-Larrán, P.; Conde, E.; Liveri, M.T.; Ribeiro, D.; Fernandes, E.; Domínguez, H. In vitro bioactive properties of phlorotannins recovered from hydrothermal treatment of Sargassum muticum. Sep. Purif. Technol. 2016, 167, 117-126. [CrossRef]

143. Lopes, G.; Sousa, C.; Silva, L.R.; Pinto, E.; Andrade, P.B.; Bernardo, J.; Mouga, T.; Valentão, P. Can phlorotannins purified extracts constitute a novel pharmacological alternative for microbial infections with associated inflammatory conditions? PLoS ONE 2012, 7, e31145. [CrossRef] [PubMed]

144. Maneesh, A.; Chakraborty, K. Unprecedented antioxidative and anti-inflammatory aryl polyketides from the brown seaweed Sargassum wightii. Food Res. Int. 2017, 100, 640-649. [CrossRef] 
145. Kim, M.; Jeong, S.-M.; Kang, B.-K.; Kim, K.B.W.R.; Ahn, D. Anti-inflammatory effects of grasshopperketone from Sargassum fulvellum ethanol extract on lipopolysaccharide-induced inflammatory responses in RAW 264.7 cells. J. Microbiol. Biotechnol. 2019, 29, 820-826. [CrossRef]

146. Balboa, E.M.; Conde, E.; Moure, A.; Falqué, E.; Domínguez, H. In vitro antioxidant properties of crude extracts and compounds from brown algae. Food Chem. 2013, 138, 1764-1785. [CrossRef]

147. Yoon, W.-J.; Heo, S.-J.; Han, S.-C.; Lee, H.-J.; Kang, G.-J.; Yang, E.-J.; Park, S.-S.; Kang, H.-K.; Yoo, E.-S. Sargachromanol $\mathrm{G}$ regulates the expression of osteoclastogenic factors in human osteoblast-like MG-63 cells. Food Chem. Toxicol. 2012, 50, 3273-3279. [CrossRef]

148. Chen, Z.; Xu, Y.; Liu, T.; Zhang, L.; Liu, H.; Guan, H. Comparative studies on the characteristic fatty acid profiles of four different Chinese medicinal Sargassum seaweeds by GC-MS and chemometrics. Mar. Drugs 2016, 14, 68. [CrossRef]

149. Narayan, B.; Hosakawa, M.; Miyashita, K. Growth inhibition of human pro-myelocytic leukemia (HL-60) cells by lipid extracts of marine alga Sargassum marginatum (Fucales, Phaeophyta) harvested off Goa (west coast of India) with special reference to fatty acid composition. Indian J. Mar. Sci. 2004, 33, 355-360.

150. Narayan, B.; Miyashita, K.; Hosokawa, M. Comparative evaluation of fatty acid composition of different Sargassum (Fucales, Phaeophyta) species harvested from temperate and tropical waters. J. Aquat. Food Prod. Technol. 2004, 13, 41-52.

151. Sanina, N.M.; Goncharova, S.N.; Kostetsky, E.Y. Fatty acid composition of individual polar lipid classes from marine macrophytes. Phytochemistry 2004, 65, 721-730. [CrossRef] [PubMed]

152. Wu, W.; Hasumi, K.; Peng, H.; Hu, X.; Wang, X.; Bao, B. Fibrinolytic Compounds Isolated from a Brown Alga, Sargassum fulvellum. Mar. Drugs 2009, 7, 85-94. [CrossRef] [PubMed]

153. Heras, B.; Hortelano, S. Molecular Basis of the Anti-Inflammatory Effects of Terpenoids. Inflamm. Allergy-Drug Targets 2009, 8, 28-39. [CrossRef] [PubMed]

154. Su, J.-H.; Dai, C.-F.; Huang, H.-H.; Wu, Y.-C.; Sung, P.-J.; Hsu, C.-H.; Sheu, J.-H. Terpenoid-related metabolites from a formosan soft coral Nephthea chabrolii. Chem. Pharm. Bull. (Tokyo) 2007, 55, 594-597. [CrossRef] [PubMed]

155. Grabarczyk, M.; Wińska, K.; Mączka, W.; Potaniec, B.; Anioł, M. Loliolide-The most ubiquitous lactone. Folia Biol. Oecologica 2015, 11, 1-8. [CrossRef]

156. National Center for Biotechnology Information PubChem Database. Fucosterol, CID=5281326. Available online: https://pubchem.ncbi.nlm.nih.gov/compound/Fucosterol (accessed on 19 July 2019).

157. National Center for Biotechnology Information PubChem Database. Sargachromanol D, CID=11247397. Available online: https://pubchem.ncbi.nlm.nih.gov/compound/Sargachromanol-D (accessed on 19 July 2019).

158. National Center for Biotechnology Information PubChem Database. Sargachromanol E, CID=11339386. Available online: https://pubchem.ncbi.nlm.nih.gov/compound/Sargachromanol-E (accessed on 19 July 2019).

159. ChemSpider Search and Share Chemistry Sargachromanol G. Available online: http://www.chemspider.com/ Chemical-Structure.9582569.html (accessed on 19 July 2019).

160. National Center for Biotechnology Information PubChem Database. Loliolide, CID=100332. Available online: https://pubchem.ncbi.nlm.nih.gov/compound/Loliolide (accessed on 19 July 2019).

161. National Center for Biotechnology Information PubChem Database. Tuberatolide B, CID=50993746. Available online: https://pubchem.ncbi.nlm.nih.gov/compound/Tuberatolide-B (accessed on 19 July 2019).

162. National Center for Biotechnology Information PubChem Database. Sargahydroquinoic acid, CID=10202734. Available online: https://pubchem.ncbi.nlm.nih.gov/compound/Sargahydroquinoic-acid (accessed on 13 August 2019).

163. Boileau, A.C.; Merchen, N.R.; Wasson, K.; Atkinson, C.A.; Erdman, J.W. Cis-lycopene is more bioavailable than trans-lycopene in vitro and in vivo in lymph-cannulated ferrets. J. Nutr. 1999, 129, 1176-1181. [CrossRef] [PubMed]

164. Nakazawa, Y.; Sashima, T.; Hosokawa, M.; Miyashita, K. Comparative evaluation of growth inhibitory effect of stereoisomers of fucoxanthin in human cancer cell lines. J. Funct. Foods 2009, 1, 88-97. [CrossRef]

165. National Center for Biotechnology Information PubChem Database. Fucoxanthin, CID=5281239. Available online: https://pubchem.ncbi.nlm.nih.gov/compound/Fucoxanthin (accessed on 19 July 2019).

166. ChemSpider Search and Share Chemistry Apo-9-Fucoxanthinone. Available online: http://www.chemspider. com/Chemical-Structure.10200226.html (accessed on 19 July 2019). 
167. Daley, D.K.; Brown, K.J.; Badal, S. Fungal Metabolites; Elsevier Inc.: Amsterdam, The Netherlands, 2016; ISBN 9780128020999.

168. National Center for Biotechnology Information PubChem Database. CID $=13922639$. Available online: https://pubchem.ncbi.nlm.nih.gov/compound/13922639 (accessed on 13 August 2019).

169. Ale, M.T.; Mikkelsen, J.D.; Meyer, A.S. Important determinants for fucoidan bioactivity: A critical review of structure-function relations and extraction methods for fucose-containing sulfated polysaccharides from brown seaweeds. Mar. Drugs 2011, 9, 2106-2130. [CrossRef]

170. Park, S.-B.; Chun, K.-R.; Jung, Y.-M.; Kim, J.-K.; Suk, K.; Lee, W.-H. The differential effect of high and low molecular weight fucoidans on the severity of collagen-induced arthritis in mice. Phyther. Res. 2010, 24, 1384-1391. [CrossRef]

171. Sinurat, E.; Saepudin, E.; Peranginangin, R.; Hudiyono, S. Immunostimulatory activity of brown seaweed-derived fucoidans at different molecular weights and purity levels towards white spot syndrome virus (WSSV) in shrimp litopenaeus vannamei. J. Appl. Pharm. Sci. 2016, 6, 082-091. [CrossRef]

172. National Center for Biotechnology Information PubChem Database. Alginic acid, CID=6850754. Available online: https://pubchem.ncbi.nlm.nih.gov/compound/Alginic-acid (accessed on 19 July 2019).

173. Li, Y.; Fu, X.; Duan, D.; Liu, X.; Xu, J.; Gao, X. Extraction and identification of phlorotannins from the brown alga, Sargassum fusiforme (Harvey) Setchell. Mar. Drugs 2017, 15, 49. [CrossRef] [PubMed]

174. Vijayan, R.; Chitra, L.; Penislusshiyan, S.; Palvannan, T. Exploring bioactive fraction of Sargassum wightii: In vitro elucidation of angiotensin-i-converting enzyme inhibition and antioxidant potential. Int. J. Food Prop. 2018, 21, 674-684. [CrossRef]

175. Glombitza, K.W.; Schmidt, A. Trihydroxyphlorethols from the brown alga Carpophyllum angustifolium. Phytochemistry 1999, 51, 1095-1100. [CrossRef]

176. Saso, L.; Valentini, G.; Casini, M.L.; Grippa, E.; Gatto, M.T.; Leone, M.G.; Silvestrini, B. Inhibition of heat-induced denaturation of albumin by nonsteroidal antiinflammatory drugs (NSAIDs): Pharmacological implications. Arch. Pharm. Res. 2001, 24, 150-158. [CrossRef] [PubMed]

177. Mizushima, Y.; Kobayashi, M. Interaction of antiinflammatory drugs with serum proteins, especially with some biologically active proteins. J. Pharm. Pharmacol. 1968, 20, 169-173. [CrossRef] [PubMed]

178. Silvestrini, B.; Gugiielmotti, A.; Saso, L.; Cheng, C. Van Changes in concanavalin-A reactive proteins in inflammatory disorders for the control rats. Clin. Chem. 1989, 35, 2207-2211.

179. Thinakaran, T.; Balamurugan, M.; Sivakumar, K. Screening of phycochemical constituents qualitatively and quantitatively certain seaweeds from Gulf of Mannar biosphere reserve. Int. Res. J. Pharm. 2012, 3, 261-265.

180. Van Ginneken, V.J.T.; Helsper, J.P.F.G.; De Visser, W.; Van Keulen, H.; Brandenburg, W.A. Polyunsaturated fatty acids in various macroalgal species from north Atlantic and tropical seas. Lipids Health Dis. 2011, 10, 104-111. [CrossRef]

181. Terasaki, M.; Miyashita, K.; Narayan, B.; Kawagoe, C.; Hosokawa, M.; Ito, A.; Kumon, H. Spatial and seasonal variations in the biofunctional lipid substances (fucoxanthin and fucosterol) of the laboratory-grown edible Japanese seaweed (Sargassum horneri Turner) cultured in the open sea. Saudi J. Biol. Sci. 2016, 24, 1475-1482. [CrossRef]

182. Airanthi, M.K.W.A.; Sasaki, N.; Iwasaki, S.; Baba, N.; Abe, M.; Hosokawa, M.; Miyashita, K. Effect of brown seaweed lipids on fatty acid composition and lipid hydroperoxide levels of mouse liver. J. Agric. Food Chem. 2011, 59, 4156-4163. [CrossRef]

183. Mori, K.; Ooi, T.; Hiraoka, M.; Oka, N.; Hamada, H.; Tamura, M.; Kusumi, T. Fucoxanthin and its metabolites in edible brown algae cultivated in deep seawater. Mar. Drugs 2008, 2, 63-72. [CrossRef]

184. Lann, K.L.; Ferret, C.; Vanmee, E.; Spagnol, C.; Lhuillery, M.; Payri, C.; Stiger-Pouvreau, V. Total phenolic, size-fractionated phenolics and fucoxanthin content of tropical Sargassaceae (Fucales, Phaeophyceae) from the South Pacific Ocean: Spatial and specific variability. Phycol. Res. 2012, 60, 37-50. [CrossRef]

185. Mouritsen, O.G.; Bagatolli, L.A.; Duelund, L.; Garvik, O.; Ipsen, J.H.; Simonsen, A.C. Effects of seaweed sterols fucosterol and desmosterol on lipid membranes. Chem. Phys. Lipids 2017, 205, 1-10. [CrossRef]

186. Fleury, B.G.; Pereira, M.V.G.; Da Silva, J.R.P.; Kaisin, M.; Teixeira, V.L.; Kelecom, A. Sterols from brazilian marine brown algae. Phytochemistry 1994, 37, 1447-1449. [CrossRef]

187. Chkhikvishvili, I.D.; Ramazanov, Z.M. Phenolic substances of brown algae and their antioxidant activity. Appl. Biochem. Microbiol. 2000, 36, 289-291. [CrossRef] 
188. Targett, N.M.; Coen, L.D.; Boettcher, A.A.; Tanner, C.E. Biogeographic comparisons of marine algal polyphenolics: Evidence against a latitudinal trend. Oecologia 1992, 89, 464-470. [CrossRef]

189. Bolser, R.C.; Hay, M.E. Are tropical plants better defended? Palatability and defenses of temperate vs. tropical seaweeds. Ecology 1996, 77, 2269-2286. [CrossRef]

190. Audibert, L.; Fauchon, M.; Blanc, N.; Hauchard, D.; Ar Gall, E. Phenolic compounds in the brown seaweed Ascophyllum nodosum: Distribution and radical-scavenging activities. Phytochem. Anal. 2010, 21, 399-405. [CrossRef]

191. Abdelkafi-Koubaa, Z.; Drira, N.; Khemakhem, B.; Mejdoub, H.; Marrakchi, N.; Chakroun, M.; El Abed, H. Antioxidant, Anti-Inflammatory, and Antitumoral Effects of Aqueous Ethanolic Extract from Phoenix dactylifera L. Parthenocarpic Dates. Biomed Res. Int. 2018, 2018, 1-7.

192. Kwak, C.S.; Son, D.; Chung, Y.S.; Kwon, Y.H. Antioxidant activity and anti-inflammatory activity of ethanol extract and fractions of Doenjang in LPS-stimulated RAW 264.7 macrophages. Nutr. Res. Pract. 2015, 9,569-578. [CrossRef]

193. Mhadhebi, L.; Mhadhebi, A.; Robert, J.; Bouraoui, A. Antioxidant, anti-inflammatory and antiproliferative effects of aqueous extracts of three mediterranean brown seaweeds of the Genus Cystoseira. Iran. J. Pharm. Res. 2014, 13, 207-220. [PubMed]

194. Zhang, L.; Ravipati, A.S.; Koyyalamudi, S.R.; Jeong, S.C.; Reddy, N.; Smith, P.T.; Bartlett, J.; Shanmugam, K.; Münch, G.; Wu, M.J. Antioxidant and anti-inflammatory activities of selected medicinal plants containing phenolic and flavonoid compounds. J. Agric. Food Chem. 2011, 59, 12361-12367. [CrossRef] [PubMed]

195. Chale-Dzul, J.; Freile-Pelegrín, Y.; Robledo, D.; Moo-Puc, R. Protective effect of fucoidans from tropical seaweeds against oxidative stress in HepG2 cells. J. Appl. Phycol. 2017, 29, 2229-2238. [CrossRef]

196. Sugiono Widjanarko, S.B.; Soehono, L.A. Extraction optimization by response surface methodology and characterization of Fucoidanfrom brown seaweed Sargassum polycystum. Int. J. ChemTech Res. 2014, 6, 195-205.

197. Wang, C.Y.; Wu, T.C.; Hsieh, S.L.; Tsai, Y.H.; Yeh, C.W.; Huang, C.Y. Antioxidant activity and growth inhibition of human colon cancer cells by crude and purified fucoidan preparations extracted from Sargassum cristaefolium. J. Food Drug Anal. 2015, 23, 766-777. [CrossRef]

198. Vijayabaskar, P.; Vaseela, N.; Thirumaran, G. Potential antibacterial and antioxidant properties of a sulfated polysaccharide from the brown marine algae Sargassum swartzii. Chin. J. Nat. Med. 2012, 10, 421-428. [CrossRef]

199. Bruhn, A.; Janicek, T.; Manns, D.; Nielsen, M.M.; Balsby, T.J.S.; Meyer, A.S.; Rasmussen, M.B.; Hou, X.; Saake, B.; Göke, C.; et al. Crude fucoidan content in two North Atlantic kelp species, Saccharina latissima and Laminaria digitata-Seasonal variation and impact of environmental factors. J. Appl. Phycol. 2017, 29, 3121-3137. [CrossRef]

200. Kokilam, G.; Vasuki, S.; Sajitha, N. Biochemical composition, alginic acid yield and antioxidant activity of brown seaweeds from Mandapam Region, Gulf of Mannar. J. Appl. Pharm. Sci. 2013, 3, 99-104.

201. Aponte de Otaola, N.E.; Diaz-Piferrer, M.; Graham, H.D. Seasonal variations and anatomical distribution of alginic acid in Sargassum spp. found along the coasts of Puerto Rico. J. Agric. Puerto Rico 1983, 67, 464-475.

202. Ehrig, K.; Alban, S. Sulfated galactofucan from the brown alga saccharina latissima-variability of yield, structural composition and bioactivity. Mar. Drugs 2015, 13, 76-101. [CrossRef]

203. So, M.-J.; Kim, B.-K.; Choi, M.-J.; Park, K.-Y.; Rhee, S.-H.; Cho, E.-J. Protective activity of fucoidan and alginic acid against free radical-induced oxidative stress under in vitro and cellular system. J. Food Sci. Nutr. 2007, 12, 191-196. [CrossRef]

204. Galis, Z.S.; Sukhova, G.K.; Lark, M.W.; Libby, P. Increased expression of matrix metalloproteinases and matrix degrading activity in vulnerable regions of human atherosclerotic plaques. J. Clin. Invest. 1994, 94, 2493-2503. [CrossRef]

205. Berry, C.E.; Hare, J.M. Xanthine oxidoreductase and cardiovascular disease: Molecular mechanisms and pathophysiological implications. J. Physiol. 2004, 555, 589-606. [CrossRef]

206. Folmer, F.; Jaspars, M.; Dicato, M.; Diederich, M. Marine natural products as targeted modulators of the transcription factor NF-кB. Biochem. Pharmacol. 2008, 75, 603-617. [CrossRef]

207. Chen, H.; Tan, H.; Yang, J.; Wei, Y.; Hu, T. Sargassum polysaccharide inhibits inflammatory response in PCV2 infected-RAW264.7 cells by regulating histone acetylation. Carbohydr. Polym. 2018, 200, 633-640. [CrossRef] 
208. Loboda, A.; Damulewicz, M.; Pyza, E.; Jozkowicz, A.; Dulak, J. Role of Nrf2/HO-1 system in development, oxidative stress response and diseases: An evolutionarily conserved mechanism. Cell. Mol. Life Sci. 2016, 73, 3221-3247. [CrossRef]

209. Lee, S.; Yeon, S.L.; Sang, H.J.; Sam, S.K.; Kuk, H.S. Anti-oxidant activities of fucosterol from the marine algae Pelvetia siliquosa. Arch. Pharm. Res. 2003, 26, 719-722. [CrossRef]

210. Makarenkova, I.D.; Logunov, D.Y.; Tukhvatulin, A.I.; Semenova, I.B.; Besednova, N.N.; Zvyagintseva, T.N. Interactions between sulfated polysaccharides from sea brown algae and toll-like receptors on HEK293 eukaryotic cells in vitro. Bull. Exp. Biol. Med. 2012, 154, 241-244. [CrossRef]

211. Russell, F.D.; Bürgin-Maunder, C.S. Distinguishing health benefits of eicosapentaenoic and docosahexaenoic acids. Mar. Drugs 2012, 10, 2535-2559. [CrossRef]

212. Tian, Y.; Katsuki, A.; Romanazzi, D.; Miller, M.R.; Adams, S.L.; Miyashita, K.; Hosokawa, M. Docosapentaenoic Acid (22:5n-3) Downregulates mRNA Expression of Pro-inflammatory Factors in LPS-activated Murine Macrophage Like RAW264.7 Cells. J. Oleo Sci. 2017, 66, 1149-1156. [CrossRef]

(C) 2019 by the authors. Licensee MDPI, Basel, Switzerland. This article is an open access article distributed under the terms and conditions of the Creative Commons Attribution (CC BY) license (http://creativecommons.org/licenses/by/4.0/). 